\title{
GEODYNAMIC RISK ZONE AT NORTHERN PART OF THE BOSKOVICE FURROW
}

\author{
Lubomil POSPÍŠIL ${ }^{1) *}$, Otakar ŠVÁBENSKÝ ${ }^{1)}$, Pavel ROŠTíNSKÝ ${ }^{2)}$, \\ Eva NOVÁKOVÁ ${ }^{2)}$ and Josef WEIGEL ${ }^{1)}$

\begin{abstract}
1) Institute of Geodesy, Faculty of Civil Engineering, Brno University of Technology, Veveri 94, 60200 Brno, Czech Republic
${ }^{2)}$ Institute of Geonics, Academy of Sciences of the Czech Republic, Departmet of Environmental Geography, Drobného 28, 60200 Brno, Czech Republic
\end{abstract}

*Corresponding author's e-mail: pospisil.1@fce.vutbr.cz

\section{ARTICLE INFO}

Article history

Received 19 January 2016

Accepted 31 March 2016

Available online 7 October 2016

\section{Keywords:}

Moravia

Nectava-Konice Fault

Železné hory-Tišnov Fault

Boskovice Furrow

GNSS

Geophysics

Horizontal and vertical velocities

\section{ABSTRACT}

After 20 years we have completed the repeated GPS measurements in the MORAVA geodynamic epoch network. This allows us to define the zones with major movement tendencies in Moravian territory. We chose one of the most anomalous and tectonically active areas, where the results of GNSS measurements in combination with earthquake data from the relevant period indicate increasing horizontal and vertical movement tendencies. This area is located at crossing of the eastern marginal faults of the Bohemian Cretaceous Basin and the Boskovice Furrow, particularly its northern part.

The paper discusses and solves following problems:

processing of all data obtained and offer a new interpretations of GPS results with the use of other geophysical and morphological information in the area where increased seismic activity appeared in the past,

interconnection and confrontation of MORAVA GPS data with CZEPOS and EPN networks, allowing further consideration of kinematic blocks located in the contact zone of the Bohemian Massif and Brunovistulicum,

presentation of a credible vertical movement tendencies gained from repeated leveling measurement along the transverse profiles of the most risky zone in the study area.

Latest results from the new measurements in the MORAVA network supplemented by the results of repeated leveling permit detection of horizontal velocities of more than $1 \mathrm{~mm} /$ year, and local vertical variations up to several centimetres, which allows the inclusion of this area in the zones of increased risk.

\section{INTRODUCTION}

One of the most important tasks concerning the GPS (Global Positioning System) and GNSS (Global Navigation Satellite Systems) results interpretation is their verification and explanation using the geomorphological, geological, geophysical, but especially seismological data. It turns up that many database information is not quite accessible for professional public, either from the cost reasons (geophysical data - Czech Geological Survey), either from the reasons of their not quite professional maintenance (Earthquake catalogues - Geophysical Institute, Czech Academy of Sciences - CAS) where inclusion of artificially induced detonations decrease the quality of the results interpreted. From these reasons we present positive and negative factors which enable readers to assess the quality of verification data and interpretation capabilities of the authors.

As positive factors we count the accessibility of following sources and databases:

- Recent lithospheric studies covering the area of Central Europe based primarily on complex analysis and interpretation of the geological, geochemical, structural and geophysical data, including the unified maps of the CR and wider surroundings (Austria, Poland),

- Complex regional development models of the Alps, the Carpathians, the Pannonian Basin and the Bohemian Massif for period of the Lower Miocene to Recent period,

- Maps with results of RVM (Recent Vertical Movements) and GPS (Global Positioning System) measurement covering whole Central Europe, results of Remote Sensing enabling to perform analysis of exogenetic dynamics at any part of the selected area.

Negative factors are

- Inaccessibility of the Earthquake Catalogue of CAS; therefore we use only the data of USGS (United States Geological Survey) and surrounding seismological stations in Austria, Switzerland and Slovakia,

- Inaccessibility of the database and original results of repeated leveling measurements (RVM - 
Vyskočil, 1996), which we substitute by analysis of repeated measurements on the 1 st order lines of the State Leveling Network.

In the article emphasis is placed on analyzing the results of repeated GPS measurements in the MORAVA network in relation to major fault systems. Significant manifestation of movement tendencies appeared at the main fault of the Boskovice Furrow and in the eastern part of the Czech Cretaceous Basin, mainly at the Nectava-Konice Fault. The benefit is to complement the results of MORAVA network by results of GNSS permanent observations at stations of the CZEPOS network. Recent activity of the area is confirmed by recent frequent occurences of earthquake foci, but also by height changes evaluated from repeated measurements on the 1st order lines of the State Leveling Network.

\section{GEOLOGICAL INFORMATION AND OBSERVATIONS OF RECENT TECTONICS}

The region can be characterized as the contact area of a few basic regional units of the Bohemian Massif - Saxothuringicum, Bohemicum, Moldanubicum, Moravian-Silesian Unit, and partly Brunovistulicum, which is within the zonal construction of Variscides integrated into Rhenohercynian Zone. From the Oligocene-Miocene period the structures of the Bohemian Massif are influenced by alpinotype dynamics created by press and movement of the Alps and the Carpathians (Malkovský, 1979 - Figure 1).

Cover rocks of the Bohemian Massif throughout the area are formed by Paleozoic, Cretaceous and in places Tertiary sediments. The Upper Paleozoic, Permian-Carboniferous basins exist in the study area, forming narrow trough-like, often asymmetric depressions already independent on the course of the main Variscan orogeny divides. The most significant is the Boskovice Furrow which has a sedimentary stratigraphic interval from the Stephanian to the end of the Permian.

The platform units include the unfolded, largely subhorizontally deposited Mesozoic, Tertiary and Quaternary sedimentary complexes, and the accompanying volcanic rocks. Depth of the platform cover units varies greatly from a few meters in case of the Quaternary to more than $900 \mathrm{~m}$ in the deepest axial parts of the Bohemian Cretaceous Basin. The platform rocks are, except for flexures or folds of a large wavelength, mostly brittle deformed only near the major fault lines that were rejuvenated during the stage known as Saxonian orogeny.

Tertiary rocks are found throughout the area of anticipated so called Elbe lineament. From structuraltectonics point of view there were last evaluated the areas of Kłodzko-Králíky Graben (Badura and Rauch, 2014) and the Upper Morava Basin (UMB - Špaček et al., 2015). Remnants of Tertiary sediments are found in the transverse broken portions of the Boskovice Furrow (Ivan, 1996). From the paleographic point of view these relics of mainly marine sediments (near
Jihlava, Moravské Budějovice and Znojmo, near Česká Třebová and Lanškroun, within the Boskovice Furrow, in the Odra Hills and in the Nízký Jeseník Mts.) were mostly associated with foreland of the Carpathians. Scattered volcanic rocks are also known in the northern part of Moravia (Malkovský, 1979).

Quaternary sediments are mostly in the continental development and individual genetic types are directly linked to the morphology of the territory, and their development is influenced by topography. In northern Moravia Quaternary comes from the denudation of mountain areas of the Králický Sněžník Massif, the Nízký and the Hrubý Jeseník Mts. Areas of Moravian basins located at contact zone of the Bohemian Massif and the Western Carpathians are characterized by significant accumulations. These areas extend into both of the units and have a somewhat different development of the Quaternary compared to the rest of the Bohemian Massif. These areas include the Upper Morava Basin with Bečva part of the Moravian Gate, Vyškov Gate, and DyjeSvratka Basin. Typical for the basins are thick complexes of the fluvial, fluviolimnic, respectively limnic sediments. Rugged border segments, bound to eastern slopes of the Bohemian Massif, are characterized by thick loess sequences of broken fossil soil complexes (especially near Brno). Quaternary has a special position in the valleys of Bečva and Morava, bound to area of continental glaciation.

Tectogenesis of the platform cover, including major faults, was analyzed in detail by Malkovský et al. (1974) and Malkovský (1979). A number of its faults have a thrust character. The definition of deep faults and fault zones in the territory covered by sediments of the Bohemian Cretaceous Basin (Figure 2) still remains disputable.

A situation of the study area within the Moravian-Silesian Unit outlined e.g. Cháb et al. (2007). It is a complex system of thrusts in the suture area of the Lugodanubicum and the Brunovistulicum whose oblique collision identifies a specific formation way of the Variscan accretionary wedge.

The various segments of the analyzed region include the larger - Nectava Crystalline, KoniceMladeč Devonian and Kladky Crystalline, and smaller crystalline occurrences of the Svinov-Vranov and Zábřeh Crystalline around. Other larger units are the northern part of the Permian-Carboniferous Boskovice Furrow in the centre of the area, sub-Orlica Permian, Mohelnice sediments of the Malonín Horst or Cenomanian to Turonian deposits of the Bohemian Cretaceous Basin (Figure 1). The oldest rocks of the Nectava Crystalline are also located in the central part of the territory. It is a complicated tectonic block uplifted along the border, which agrees with the Nectava-Konice Fault System forming the western limit of the Bouzov Culm. The Nectava block (NK) and the Kladky crystalline (KF) represent the Devonian basement. Over the KF, which is considered as Brunovistulicum relict (Bábek et al., 2006), is thrusted the Culm. 
The Nectava block is to the northeast limited by the Vojtěchov Fault which also divides the KoniceMladeč band (DV) into two completely different units. This complex is formed by rocks of the Drahany development, according to Bábek et al. (2006) thrusted on the transitive Devonian development and its Brunovistulian base along the southward slightly tilted thrust line of the $\mathrm{W}$-E direction.

Many of the above recently active fault zones exploit an older, often Variscan divides (e.g. Boskovice Furrow) which may be essential in terms of regional interpretation of the tectonic situation in the region of interest.

\section{GEOPHYSICAL IMAGE OF THE AREA}

Geophysical image of the study area is best described by maps of gravity and magnetic anomalies (Fig. 3). The anomalous manifestations correspond fairly well with the layout of the main geological units, their density and magnetic manifestations.

The area of interest is located within the geologically most complex part of the Bohemian Massif. Opinions on its deeper building vary considerably and cannot be explicitly interpreted in the area without seismic data. The dominant feature is the Svitavy magnetic and gravity anomalies, located in the tectonic zone formed by Nectava - Konice Fault and Boskovice Furrow. The sources of this anomalous zone consist of amphibolites and ultrabasic complex (serpentinites), which are assigned to the Letovice Crystalline (Šalanský and Gnojek, 2002). The magnetic and gravity anomalies continue up to Ústi nad Orlici town. Both anomalies are delimited by Nectava -Konice tectonic zone. It is assumed that the entire complex, which is irregularly distributed under Cretaceous sediments, belongs to complexes of Saxonthuringicum. Linking to the SE it is limited by the course of Boskovice Furrow. Its importance and recent manifestation described in detail Roštínský et al. (2013).

Gravity measurements were carried out on nine points of the geodynamic networks HIGHLANDS and WEST SUDETEN and five sites of the Czech Gravity Reference Network (Kujal et al., 2009).

General geophysical image fairly well defines tectonic subdivision and block structure of the area. Especially strongly manifested are the graben structures (Králíky, UMB, Mohelnice), active from Tertiary to Recent (Grygar and Jelínek, 2003).

\section{SEISMIC ACTIVITY}

Detail studies of seismological events were published by many specialists (e.g. Skácelová and Havíŕ, 1999; Lenhardt et al., 2007; Špaček et al., 2008, 2015). Manifestations of feeble natural seismic activity were registered mainly at eastern margin of the Bohemian Massif.

Latest geodynamic studies of the Nysa-Klodzko Graben (Badura and Rauch, 2014) and the Upper Morava Basin (UMB - Špaček et al., 2015) enable to prove new recent tectonic activities in both areas.
Even though the geodynamic and seismological studies of above mentioned authors were devoted mainly to the northern part of Moravia or have a regional character, we have found in USGS and CAS Earthquake databases important detail information concerning the Northern part of the Boskovice Furrow (Figs. 4 and 5).

There is a dense cluster of earthquake foci with magnitudes (M) from 1 to $3 \mathrm{M}$ surrounding the Boskovice town. Important is the fact that most of them lay in depths $5 \mathrm{~km}$, but there are also foci seated in depth interval between 10 and $20 \mathrm{~km}$. Similar hypocenter depths (between 7 and $19 \mathrm{~km}$ ) were reported in the northern part of Moravia (Špaček et al., 2008). Next remarkable feature, but very problematic in relation to their sources, is the location of foci along main known faults of NW-SE direction near town of Svitavy (Figs. 4, 5). Next specific structure is observable on the Železné Hory - Tišnov Tectonic Zone (ZHTTZ) with problematic shallow foci, too. Reliable determination of the source is unclear. Most of them are considered as effects induced by local quarries?! Although we can doubt about real existence of tectonics, the morphological image and signs and geological records suggest a compressive zone where there are in contact complexes of different levels of the crust. On the northern side of ZHTTZ there are upper crustal complexes, and to the south there are lower crustal complexes.

Another earthquake (3M) was located near the Polička town, in place through which goes the marginal fault of the Bohemian Cretaceous Basin. Explanation of its role is unclear, too.

On the other hand, the explanation of the swarm of earthquakes at the eastern margin fault of the Boskovice Furrow can be combined with the recent activity of the Nectava - Konice Fault, which Badura and Rauch (2014) consider as a direct continuation of the Jílovice Fault. This fault reaches very deep to basement after Malkovský (1979), what could explain the existence of foci with magnitude higher as $3 \mathrm{M}$ at depths between 5 and $18 \mathrm{~km}$ minimally (Fig. 5).

\section{GEOMORPHOLOGICAL ANALYSES}

Remarkable results, in comparing with geodetic data offer new geomorphological study of risk place in the Boskovice Furrow zone. The study area is situated in the region of SE denudation margin of the Bohemian Cretaceous Basin of lower tableland character (dominantly Upper Cretaceous sedimentary siliciclastic rocks; e.g. Frejková, 1960; Malkovský et al., 1974; Čech et al., 1980; Valečka 1988; Skácelová et al., 2008), wedging in between the BohemianMoravian Highland in the SW and the Brno Highland, the Zábřeh Highland and the Orlické hory Mts. in the $\mathrm{S}, \mathrm{SE}$ and E, respectively (pre-Variscan crystalline rocks, in the SE covered by thick Devonian to Lower Carboniferous deposits (Figure 6 - Demek and Mackovčin, 2006; Demek et al., 2009). The Bohemian Cretaceous Basin together with the BohemianMoravian Highland and the latter upland areas are 
separated by a narrow zone mainly of lower location the NNE-SSW trending Boskovice Furrow filled with Permo-Carboniferous sediments elongated along the Diendorf-Boskovice Fault (e.g. Ivan, 1996; Roštínský et al., 2013), northward loosely interconnected with the asymmetric NNW-SSE trending Lanškroun Basin filled with Cretaceous deposits (Svoboda, 1962; Ivan, 1996); older bedrock is locally outcropping at the junction area of both sub-structures.

Moreover, during Cenozoic the geological structure was strongly influenced by Saxon tectonics leading to (1) folding and faulting of Upper Cretaceous domain of dominating NW-SE, NNWSSE to N-S trends (e.g. Vavř́nová, 1946; Frejková, 1960; Malkovský, 1977; Grygar and Jelínek, 2003; Valigurský and Čech, 2003; Špaček et al., 2015); (2) updoming of adjacent crystalline regional units within the Upper Svratka Highland and the Drahany Highland (Hrádek, 1982; Ivan, 1996); (3) regional marine transgression together with siliciclastic and carbonate deposition during Miocene/Lower Badenian stage (Cícha and Dornič, 1959; Svoboda, 1962); and (4) related strong differential denudation of Cretaceous and Miocene deposits from above uprising sub-areas whereas thicker sedimentary sequences have been preserved in intervening half-grabens (e.g. Cícha and Dornič, 1959; Valečka, 1988; Ivan, 1996; Skácelová et al., 2008) and/or Plio-Pleistocene strata newly deposited in the SE within the Upper Morava Basin system (Grygar and Jelínek, 2003; Špaček et al., 2015). During these complex movements, a system of asymmetric anticlines and synclines evolved in the study Cretaceous terrain, modified into landforms of slightly bending, generally $\mathrm{N}-\mathrm{S}$ directed cuestas and flexures (Kozlov Ridge, Hřebeč Ridge) of Cretaceous rocks and adjacent asymmetric elongated basins (Ústí nad Orlicí Furrow, Moravská Třebová Basin, Lanškroun Basin, northernmost tip of the Boskovice Furrow; Ivan, 1996; Demek and Mackovčin, 2006; Demek et al., 2009).

The processed geomorphological analysis, assessing main linear topographic features topolineaments (Figure 6), especially focused on structures transversal or oblique to the DiendorfBoskovice Fault (Boskovice Furrow) trend. In accordance with Špaček et al. (2015), NW-SE, NNW-SSE to N-S directions and completed with WNW-ESE one were included among this class. Other directions, frequently sub-parallel to the Boskovice Furrow structure, were marked in another way. In addition, water-gap valleys through relatively higher relief segments were highlighted as they are mostly taking for landforms developed by antecedence combined with epigenesis from above Cretaceous sedimentary cover and/or locally also younger Miocene deposits; their occurrence could thus indicate quite recent uplift within respective landforms (cf. Ivan, 1996). Many sections of regional fluvial network are also characterized by linear courses showing their possible close relation to old and especially young Saxon structural conditions.
DEM based on ZABAGED (Geographical Database of CR; 2013) contour data by the Czech Office for Surveying, Mapping and Cadastre was constructed and main distinct linear features were defined; the process was also supported by more detailed visualization of Lidar data - product DMR 4G (Digital elevation model of 4th generation; 2015) from the same national provider. Major linear trends in the study area were compared with available Czech and USGS seismic databases for indicating of possible interrelations between both phenomena.

In the Boskovice Furrow, only a few longitudinal linear NNE-SSW to NE-SW features are evolved along eastern margin of its NE part (flat-surfaced Malá Haná sub-unit) with the Drahany Highland. In the SW study segments of this landform, hilly terrain also occur and the lower geomorphological structure is interrupted by the Žernovník Horst representing a higher threshold (usually taken for a tip of the Bohemian-Moravian Highland) towards main SW part of this pronounced linear feature (Demek and Mackovčin, 2006). Within the water-gap valley sections, linear trends are quite common indicating local significant structural precondition even of these specific parts of regional fluvial system.

Main Transversal Features - Among major transversal or oblique structures to the Boskovice Furrow trend belong following ones (modified mostly after Ivan (1996), Špaček et al. (2015) and completed); however, none of them directly manifest on the depression bottom - only a few remnants of Cretaceous deposits occur within higher segments of this lower landform unit:

1. Semanín zone; NNW-SSE to N-S direction, partly trending along regionally significant Semanín fault (also Malkovský, 1979; Hrádek, 1982). The main geomorphological feature is represented by the asymmetric Blansko Graben structure in the $\mathrm{S}$, partly filled with Cretaceous sediments, with more pronounced W slope elevating more than $250 \mathrm{~m}$. The Cretaceous deposits occur as a denudation remnants in linear area of the same direction towards NNW up to Kunštát in the southern foreland of continuous Cretaceous occurrence (both in the Boskovice Furrow and the margin of the BohemianMoravian Highland) forming there conversely several buttes evidencing significant relief inversion (Ivan, 1996).

2. Valchov zone; NW-SE direction. Its most prominent landform includes asymmetric Valchov Graben with more striking SW slope reaching nearly $250 \mathrm{~m}$. It is partly filled with Cretaceous deposits, continuing like small remnants also towards the NW vicinity of Boskovice in the Boskovice Furrow. Except for neotectonic activity, also old structural predisposition of the distinct SW geomorphological line is highly possible (cf. Dvořák et al., 1984). 
3. Nectava-Konice zone; NW-SE direction. Its major geomorphological features are (1) two counter-directed adjacent linear valleys interconnected via wind-gap section crossing the higher Brno Highland (Drahany sub-unit)/Zábřeh Highland domain and (2) greater surface segmentation by shorter linear depressed landforms on the SE margin of the Drahany Highland towards the Upper Morava Basin (UMB), also including $150 \mathrm{~m}$ high steep SW linear slope of the Velký Kosír Upland; other topographic manifestations occur both in the UMB farther towards SE and in the southern segment of the Zábřeh Highland towards NE (cf. Špaček at al., 2015).

4. Bouzov zone; general WNW-ESE direction. Its main surface element includes the locally enlarged water-gap Třebůvka valley crossing the Zábreh Highland from the $\mathrm{NE}$ tip of the Boskovice Furrow towards the $\mathrm{S}$ tip of the Mohelnice Graben. Numerous W-E to WNWESE linear trends are developed within its landforms.

5. Also the area around the southern end of the Králíky Graben located approximately $30 \mathrm{~km}$ northward from the Boskovice Furrow representing southern tip of the geomorphologically striking Klodsko Graben (Valečka, 1988; Demek and Kopecký, 1998) - Bušín zone of WNW-ESE direction (partly supported by prominent Bušín Fault - e.g. (Malkovský, 1979; Grygar and Jelínek, 2003) - can be classify as similarly oriented significant transversal system. It crosses higher mountain terrain of the Zábřeh / Hanušovice Highlands towards the analogously $\mathrm{N}-\mathrm{S}$ situated Mohelnice Graben and farther towards SE loosely interconnects with the distinct fault on NE margin of the UMB (Temenice Fault; e.g. Špaček et al., 2015).

Topographic Relation to Seismic Events Visualization of earthquake epicenters from three available databases together with regional system of linear landforms (Figs. 4, 5) does not clearly show any close relation between both phenomena; however, some general notes can be mentioned regarding to the catalogues of the U. S. Geological Survey (1977-2012 events) and the Czech Academy of Sciences (19862015 events):

1. A concentration of more significant earthquakes (USGS) at junction of the NE tip of the Boskovice Furrow with transversal NectavaKonice zone is especially remarkable; an interplay of both different neotectonic systems seems thus to be involved in this higher seismic activity.

2. CAS earthquakes evidently aggregate more into groups transversal or oblique to the Boskovice Furrow zone, i.e. generally in directions preferred by topographic features in zones accentuated above. But they only poorly occur just within them.
3. The highest concentration of seismic events in the vicinity of Boskovice (CAS), partly located at junction of the Boskovice Furrow with the Valchov zone region seems to be spatially interconnected with the areas situated farther towards the NW along the Křetínka valley and in the surroundings of Polička, both with remarkable neotectonic landscape features (cf. Ivan, 1991, 1992); conversely, in the adjacent Cretaceous domain only scarce earthquakes were registered.

4. Only rare events were detected at the geomorphologically prominent Králíky Graben area whereas southwards along the northern side of the Moravská Sázava valley section a WNWESE belt of seismic phenomena sub-parallel to the Bušín zone is obvious; this could also indicate significant neotectonic evolutionary redisposition of this water-gap landform, although not so clear like at the Třebůvka water-gap section nearby.

\section{GEODYNAMIC MONITORING NETWORKS \\ 6.1. GPS/GNSS DATA}

Geodynamic monitoring activities at the territory of Moravia started more than 20 years ago, when the local geodynamic SNĚŽNÍK network was founded in the Czech-Polish cooperation of Brno University of Technology (BUT) and Academia Rolnicza Wrocław in 1992 for the purpose of monitoring the Králický Sněžník Massif. In 1994 the MORAVA network was established within larger geodynamic project of Technical University Ostrava and Czech Technical University Prague covering contact area between eastern margin of the Bohemian Massif and the Western Carpathians. Then the following regional networks were established by the Institute of Rock Structure and Mechanics, Czech Academy of Sciences in Prague: the EAST SUDETEN network in 1997 (Schenk et al., 2003), the WEST SUDETEN network in 2001 (Schenk et al., 2001) and the HIGHLANDS network in 2005 (Schenková et al., 2007). Several more local geodynamic networks were built in the last period in different parts of Moravia territory, e.g. the ZNOJMO and TETČICE networks established by BUT Brno. All the networks mentioned were built as GPS epoch-wise networks with points embedded directly in bedrock, with forced centering of GPS antennas.

Important for processing and evaluation of GPS measurements is the regional reference frame with reliable estimated velocities. Such frame is composed usually from long-term observing permanent GNSS stations well distributed over the area concerned and its surroundings. First permanent GNSS station in the Moravia territory was the TUBO station in Brno built in 1994 firstly as epoch-wise, and observing permanently since 2001. The TUBO station is included in Euref Permanent GNSS Network (EPN) and is declared as Class A station which can be used as fiducial for densification purposes, alike the BISK permanent station belonging to geodynamic network 
Table 1 Morava network - baseline length changes and related velocities.

\begin{tabular}{|c|c|c|c|c|c|c|c|c|}
\hline Baseline & $\begin{array}{c}\text { Difference } \\
\text { 1995-2010 } \\
{[\mathrm{m}]} \\
\end{array}$ & $\begin{array}{c}\text { Velo- } \\
\text { city } \\
{[\mathrm{mm} / \mathrm{y}]}\end{array}$ & Baseline & $\begin{array}{c}\text { Difference } \\
1995-2013 \\
{[\mathrm{~m}]} \\
\end{array}$ & $\begin{array}{c}\text { Velo- } \\
\text { city } \\
{[\mathrm{mm} / \mathrm{y}]}\end{array}$ & Baseline & $\begin{array}{c}\text { Difference } \\
\text { 1995-2014 } \\
{[\mathrm{m}]} \\
\end{array}$ & $\begin{array}{c}\text { Velo- } \\
\text { city } \\
{[\mathrm{mm} / \mathrm{y}]}\end{array}$ \\
\hline TUBO-NAHO & 0.0043 & 0.3 & TUBO-CELE & -0.0041 & -0.2 & TUBO-RASO & -0.0020 & -0.1 \\
\hline TUBO-DUKO & -0.0030 & -0.2 & TUBO-BUDI & -0.0052 & -0.4 & RASO-VRSA & -0.0146 & -1.0 \\
\hline TUBO-STOH & 0.0098 & 0.7 & TUBO-HELI & -0.0125 & -0.7 & KOBR-MANA & 0.0035 & 0.2 \\
\hline TUBO-VRSA & 0.0145 & 1.0 & TUBO-VAVR & 0.0031 & 0.2 & TUBO-MANA & 0.0010 & 0.0 \\
\hline NAHO-DUKO & 0.0043 & 0.3 & SVIN-SLAV & -0.0080 & -0.3 & RASO-ZLIE & -0.0050 & -0.3 \\
\hline NAHO-STOH & -0.0014 & -0.1 & TUBO-SLAV & -0.0072 & -0.4 & CELE-VAVR & 0.0018 & 0.1 \\
\hline NAHO-VRSA & 0.0234 & 1.6 & BUDI-VAVR & -0.0134 & -0.9 & TUBO-ZLIE & -0.0049 & -0.3 \\
\hline STOH-DUKO & 0.0009 & 0.1 & BUDI-HELI & 0.0110 & 0.6 & MOPI-VRSA & 0.0116 & 0.7 \\
\hline STOH-VRSA & 0.0283 & 2.0 & CELE-SVIN & 0.0039 & 0.3 & TUBO-KOBR & -0.0017 & -0.1 \\
\hline DUKO-VRSA & 0.0143 & 1.0 & CELE-HELI & 0.0004 & 0.0 & TUBO-SVIN & -0.0021 & -0.1 \\
\hline
\end{tabular}

GEONAS of the the Institute of Rock Structure and Mechanics, Czech Academy of Sciences (Schenk et al., 2010) which was built later in 2001 near Zlaté Hory town in Northern Moravia. The CZEPOS permanent network has operated since 2005 with several stations located within Moravia territory. Data of private GNSS permanent networks TOPNET (built by the Geodis Brno Ltd. in the period 2004-2010, now operated by the GB-Geodezie Brno Ltd.) and Trimble VRS NOW CZECH (operated by Geotronics Prague Ltd. since 2009) are partly usable as complementary one. Data from permanent stations in surrounding countries (Slovakia, Poland, Austria, Hungary) are also usable.

For our evaluations the regional velocity field published in (Hefty, 2007) and (Hefty et al., 2010) was used as a reference frame for estimation of detailed kinematic trends and movement tendencies over the Moravia area (corresponding velocity vectors are shown in Figure 2). Locations of the MORAVA and CZEPOS network points are shown in Figure 7.

\subsubsection{MORAVA NETWORK}

The GPS geodynamic MORAVA network was established in 1994 for the purpose of monitoring the crustal movements at contact zone between the Bohemian Massif and the Western Carpathians. The network points are distributed over the area extending from eastern part of the Bohemian Massif to western part of the Carpathians. The campaigns realized in period 1994 - 1996 within the original project and obtained results are described in detail in (Foldyna et al., 1997). After 1996 the measurements did not continue.

In period 2010-2014 the Institute of Geodesy of Brno University of Technology realized three partial new measuring campaigns in the Morava network. The activities were preceded by detailed inspection of point markers state and assessment of actual observation conditions at all network points. Centering markers were found in good state enabling identical mounting of GNSS antennas, even at TUBO permanent station the contemporary antenna centering coincides with position of the original Morava point.
In one case only (point VYHO near Budišov) the observing conditions were substantially degraded by grown vegetation.

In 2010 four points at Southern Moravia (DUKO, NAHO, STOH and VRSA) were remeasured in one diurnal campaign. In 2013 another six points were re-measured in Central and Northern Moravia (BUDI, HELI, VAVR, CELE, SVIN and SLAV). Re-measurement continued also in 2014 with five included points - KOBR and MANA in Northern Moravia, ZLIE in Slovakia, RASO and VRSA in South-Eastern Moravia. The data from permanent station TUBO were included into processing of all the campaigns as reference.

In all the campaigns mentioned the Leica instrumentation (SR520/530 and GX1230GG receivers with LEIAT502, LEIAX1202GG a LEIAT504/504GG antennas) was used, complemented by two Topcon HiPER Plus and one Trimble 5700 receivers in last two campaigns. The data were processed with the BSW 5.0 (Dach et al., 2007), using unified standard processing and evaluating procedure described e.g. in (Švábenský et al., 2011). The original data from campaigns 1995 and 1996 were reprocessed too to ensure consistency of results. Velocities of baseline changes were estimated from differences between the results of previous and new measurements, as is shown in Table 1 and depicted in Figure 8. In Table 1 the baseline length changes over displayed period and their estimated velocities are shown (significant values are in bold).

\subsubsection{CZEPOS PERMANENT NETWORK}

The GNSS permanent CZEPOS network has been operating since 2005 as a part of the Czech national geodetic infrastructure. It was helpful to use the data of selected stations of CZEPOS network as complementary in the analysis, despite the fact that its quality for the purpose of displacement monitoring is slightly lower because the antennas are mounted on building roofs. The data from CZEPOS stations with longer observation history CDAC, CPAR, CFRM, CSVI, CSUM, CBRU, CVSE, CKRO, CHOD were used in our analyses, taking into account the jumps in 


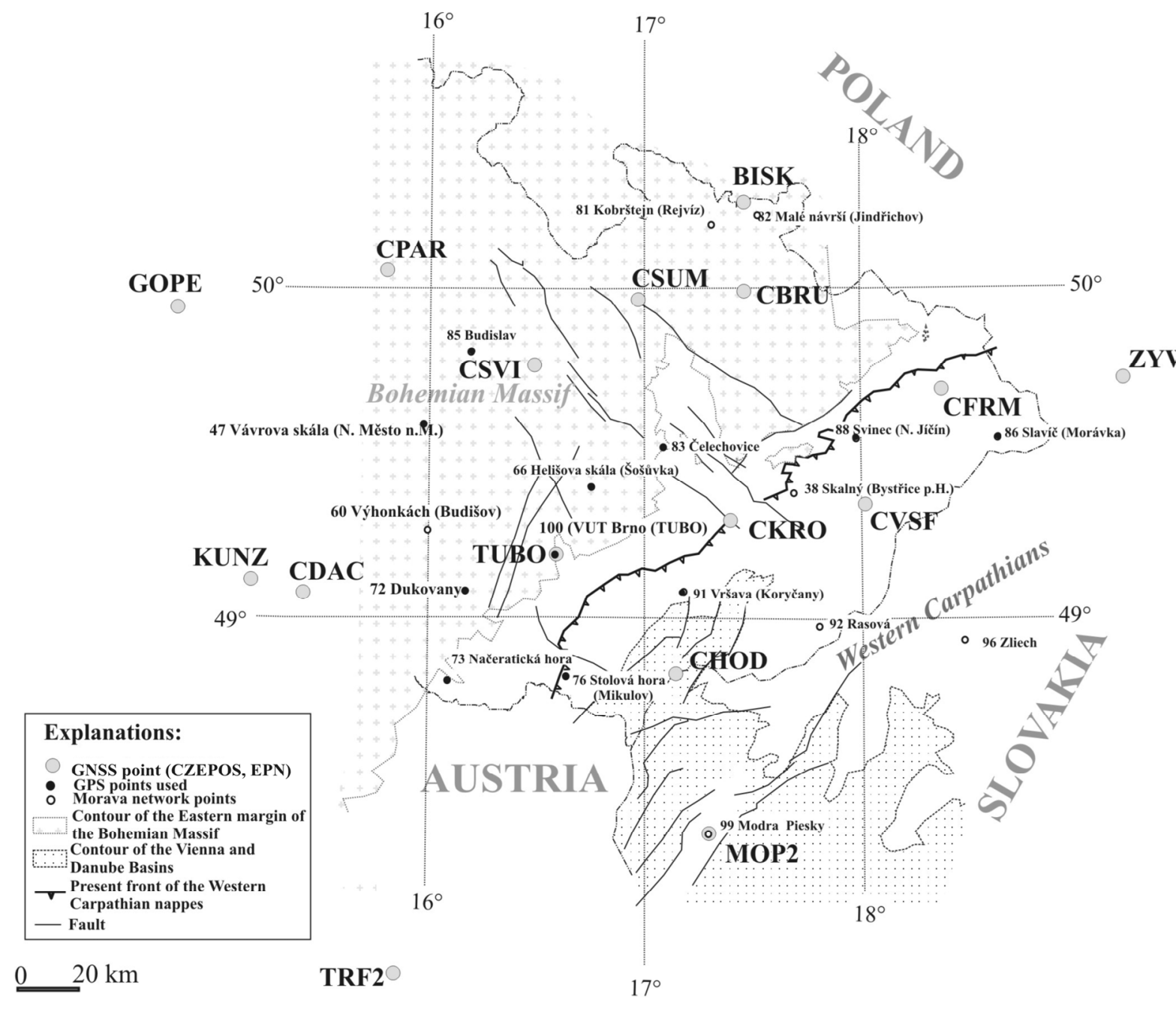

SPRN

Fig. 7 Location of the EPN, MORAVA and CZEPOS networks points.

coordinate series due to antenna change and receiver upgrade in complete CZEPOS network in the first half of 2012 (www.cuzk.cz).

\subsubsection{EUREF PERMANENT GNSS NETWORK (EPN)}

The data from EPN stations (www.epncb.oma.be) on territory of CR within and nearby the Moravia area TUBO, BISK, GOPE, KUNZ, CPAR, CFRM, together with data from selected suitable EPN stations in surrounding countries - MOPI and MOP2 (SK), WROC and ZYWI (PL), TRF2 (AU), SPRN (HU) served for definition of coordinate reference frame for our computations, so as the EPN stations are continually monitored and have well defined EUREF coordinates and velocities.

Table 2 shows the newly estimated velocities of baseline changes between the stations of CZEPOS and EPN networks which may serve for first assessment of the positional stability of the CZEPOS stations used for investigation of movement tendencies over the Moravia territory. In the table the baseline lengths and their estimated velocities are shown (significant values are in bold). The velocities were derived on base of linear trend estimation on the single baseline time series over period $2005-2014$. Overall accuracy (standard deviation) of the velocity estimation is around $0.3 \mathrm{~mm} /$ year. It is possible to get rough ideas about the CZEPOS network point stability in respect to EPN points as well as mutually within the Moravia area from Figure 9.

The results of new repeated GPS measurements in the MORAVA network were completed in 2014. Selected points of EPN and CZEPOS networks were also processed parallely with MORAVA network points (Figure 5 - Švábenský et al., 2011, 2014). The purpose was to compare the movement tendencies on all the networks. Finally we used for comparison also the results gained at the CEGRN network (Hefty, 2007; Hefty et al., 2010). This step was needed for control of regional relationship during the interpretation. All geodetic information about horizontal movement tendencies has been confronted with geophysical and geomorphological data available. Distinct tectonic pattern constructed in such way on base of the geodetic results indicates good correlation with geophysical phenomena (magnetic, gravity anomalies, earthquake foci etc.). 


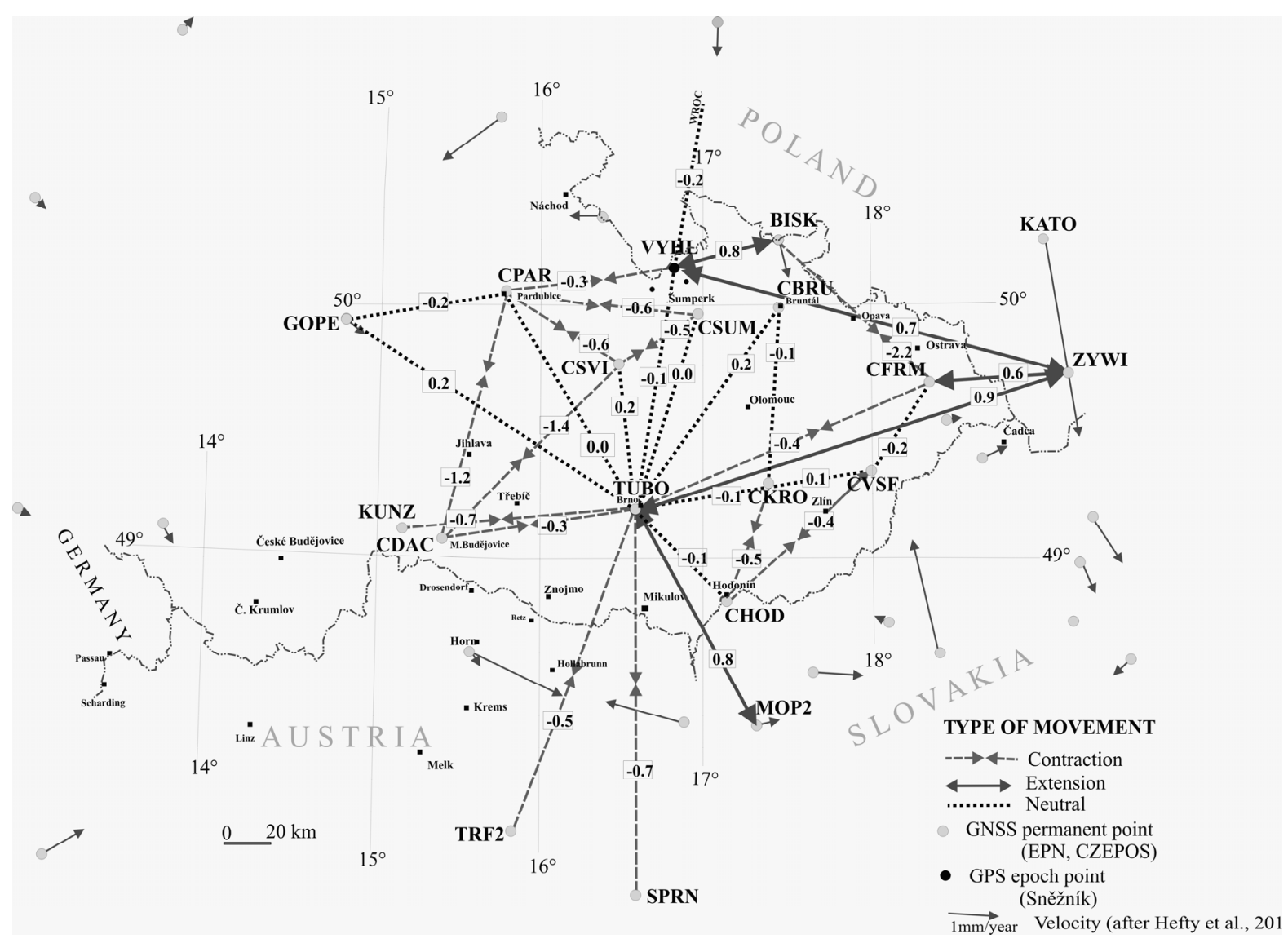

Fig. 9 Indication of the major movement tendencies between selected GPS points in Moravian part of the CZEPOS network. The regional character of movements can be observed from data of Hefty (2007), and Hefty et al. (2010) (arrows).

Table 2 CZEPOS and EPN networks - baselines and velocities.

\begin{tabular}{|c|c|c|c|c|c|c|c|c|}
\hline Baseline & $\begin{array}{c}\text { Baseline } \\
\text { length } \\
{[\mathrm{km}]} \\
\end{array}$ & $\begin{array}{c}\text { Velo- } \\
\text { city } \\
{[\mathrm{mm} / \mathrm{y}]}\end{array}$ & Baseline & $\begin{array}{c}\text { Baseline } \\
\text { length } \\
{[\mathrm{km}}\end{array}$ & $\begin{array}{c}\text { Velo- } \\
\text { city } \\
{[\mathrm{mm} / \mathrm{y}]}\end{array}$ & Baseline & $\begin{array}{c}\text { Baseline } \\
\text { length } \\
{[\mathrm{km}}\end{array}$ & $\begin{array}{c}\text { Velo- } \\
\text { city } \\
{[\mathrm{mm} / \mathrm{y}]}\end{array}$ \\
\hline TUBO-GOPE & 152.6 & -0.1 & TUBO-KUNZ & 102.1 & -0.4 & TUBO-WROC & 214.8 & -0.2 \\
\hline TUBO-CPAR & 109.6 & 0.0 & CFRM-CVSE & 46.6 & -0.2 & TUBO-ZYWI & 196.9 & 0.2 \\
\hline TUBO-CSVI & 62.0 & 0.2 & CVSE-CKRO & 43.2 & -0.1 & TUBO-GOPE & 152.6 & -0.1 \\
\hline TUBO-CSUM & 89.0 & 0.0 & CVSE-CHOD & 83.1 & -0.4 & TUBO-TRF2 & 152.1 & 0.1 \\
\hline TUBO-CBRU & 107.6 & 0.2 & CFRM-ZYWI & 61.5 & 1.0 & TUBO-SPRN & 169.3 & 0.7 \\
\hline TUBO-CFRM & 138.3 & -0.4 & BISK-VYHL & 44.9 & 0.6 & TUBO-MOP2 & 105.3 & 0.8 \\
\hline TUBO-CVSE & 102.8 & 0.0 & CKRO-CBRU & 38.1 & -0.1 & GOPE-CPAR & 72.9 & 0.2 \\
\hline TUBO-CHOD & 55.7 & -0.1 & CFRM-BISK & 91.9 & -1.8 & CPAR-CDAC & 109.7 & -1.2 \\
\hline TUBO-CKRO & 59.7 & 0.1 & ZYWI-VYHL & 178.5 & 0.7 & CPAR-CSUM & 86.3 & 0.0 \\
\hline TUBO-CDAC & 85.5 & -0.3 & CSVI-CDAC & 106.4 & -1.4 & CPAR-CSVI & 58.5 & -0.1 \\
\hline TUBO-VYHL & 105.8 & -0.1 & CSUM-CSVI & 43.3 & 0.0 & CKRO-CHOD & 53.6 & -0.5 \\
\hline
\end{tabular}

\section{CRITICAL ASSESSMENT OF THE DATA}

On the territory of South Moravia particularly the Diendorf-Čebín Tectonic Zone (DCTZ) and the Bulhary Fault play dominant role (Švábenský et al., 2011; Pospíśil et al. 2009, 2010). More detailed distribution of GPS/GNSS points could improve information on movement tendencies in Flysch zone. GPS measured results presented in Figure 8 clearly demonstrate obtained measurable contraction tendencies (Švábenský et al., 2011) between contact zone of the Bohemian Massif and tectonic units of the Western Carpathians, directly in Flysch belt. Quite opposite results - extension tendencies have been measured in the southern part of contact zone.

Maximal horizontal deformations occur between points BUDI and VAVR of the MORAVA network, with contraction character (-0.8 mm/year - Fig. 8), while between the both points mentioned and the point HELI an extension character of deformations is displayed $(+0.8 \mathrm{~mm} /$ year $)$.

A large compression field at the area of Central and Northern Moravia (Fig. 8) could indicate the influence of the Carpathian Arc, what was already mentioned by Schenková et al. (2007, 2009). The 
same features have been indicated in the Eastern Moravia, what is supported by uplifts in the Beskydy and Jeseníky Mts. (Vyskočil, 1996), or rather the action of the Moldanubian part of the Bohemian Massif on Brunovistulian belt. It is also supported by preliminary results of GPS measurements at South Moravia (Pospíšil et al., 2010; Švábenský et al., 2011, 2013; Roštínský et al., 2013). Schenková et al. (2009) report even the regional movements $1-2 \mathrm{~mm} /$ year on faults at southern parts of the Boskovice Furrow, interpreted as sinistral at southern part and dextral in northern part.

The movement tendencies, obtained on the basis of GPS results are confronted not only with geomorphological and geophysical data through GIS but also with a repeated levelling measurement (Vyskočil, 1996).

The contact area of the Bohemian Massif and the Carpathians is characterized by rather intensive vertical movement activity reaching relative values up to $5 \mathrm{~mm} /$ year (Vyskočil and Zeman, 1980; Vyskočil, 1996). In the area of our interest the vertical movements are of maximal values from -2 to $+2.4 \mathrm{~mm} /$ year and are bound to the ZHTTZ zone. Although the territory of Moravia is rather differentiated as to the vertical deformations, the relative movements reach maximal values $3 \mathrm{~mm} /$ year only in Southern Moravia area.

Leveling is one of the classical methods useful for detection of vertical movements of the Earth's crust and recent geodynamics. Territory of the Czech Republic (former Czechoslovakia) is covered by the State Leveling Network lines of several orders. The heights of benchmarks are determined in the system of normal heights (Balt - Kronstadt). Some of the leveling lines in the study area were analyzed for changes of benchmark heights. The paper presents the results of the analysis of repeated measurements of leveling line first order EF Králíky- Svitavy in two epochs - 1948 and 1976 and on part of this line in the epoch 1993.

Position of the active Nectava - Konice tectonic zone is detected by repeated leveling profile (RLP) near the Lanškroun town (Figures 10, 11 and 12). On the geological section (modified after Geological map of the CSSR, Sheet Moravská Třebová-ÚÚG Praha) is main subsidence zone near the Lanškroun town. Values of benchmark height changes are shown in Table 3.

\section{GEODYNAMIC MODEL OF THE STUDIED AREA}

Geodynamic evaluation of GPS/GNSS measurements and on basis of these derived movement tendencies is based on comparison of the geological structure with geodetic (RVM) and geophysical data (GRAV/MAG, earthquake foci), and structural relations determined from borehole database, archival seismic and geoelectric (VES) measurements (Skácelová, Z., personal communication).
The evaluation of chosen detected risk area on the base of GPS measurements and earthquake foci is one way to utilize the geodetic data in praxis. Similar way can be followed also in the last synthetic interpretation works (Špaček et al., 2015; Badura and Rauch, 2014).

The GPS data evaluation results prove that the area of northern part of the Boskovice Furrow is seismically active combined with single faults. There are noticeable morphotectonic and kinematic signs (facets, changes of river flows etc. - Fig. 13) observable on the satellite and aerial photos. These are also observable in realized InSAR and available SRTM data (CUZK and USGS/NASA).

Preliminary geodynamic image of the analysed area is depicted in Figure 13, where the main active risk area delimited by recently active Nectava-Konice Fault Zone is shown. The post-alpine grabens Blansko, Moravská Třebová - Lanškroun are also tied to this zone (Badura and Rauch, 2014). The end of the Boskovice Furrow, that is connected to graben structures mentioned north of Boskovice, represents the most risk area accompanied by recent earthquakes of magnitudes up to M3 with depths to $18 \mathrm{~km}$ (USGS Database). It is a parallel tectonic structure in relation to the system of graben structures - UMB, Mohelnice, Králíky grabens (Špaček et al., 2015), and Upper Nysa - Kłodzko Graben (Badura and Rauch, 2014). Southern limitation of the area constitutes the morphotectonically distinctive zone of the Železné Hory - Tišnov Tectonic System.

Next step to its improvement will be processing and interconnection of the HIGHLANDS, SNĚŽNÍK, EAST SUDETEN and MORAVA geodynamic networks. The outputs from permanent stations of the EPN and CZEPOS networks will serve as checking.

Quite different situation is in surrounding area of the Boskovice furrow in the Southern Moravia. This is one of the regions with the lowest seismic activity in the Czech Republic. Reports on historical earthquakes in this area are sporadic and poorly evidenced, many of the messages are in fact information on felt earthquakes originating mainly in Austria (Pazdírková et al., 2015). It was generally assumed that no stronger earthquakes will occur in this area, in spite of their annual occurrence on the Diendorf Fault in Austria. Thereafter only three local earthquakes were recorded here (Pazdírková et al., 2015) - near Hostěradice in 2000 and 2014 and near Božice in 2006 (magnitude 1.4). The earthquake of August 17, 2000 had the focus south of Hosterradice, with magnitude of 2.5. This earthquake was registered only instrumentally, its location was not quite accurate due to lack of surrounding nearby stations. The shock of 2000 had probably the focus of much greater depth (about $18 \mathrm{~km}$ ), which in addition to localization suggests besides the signal character also the absence of macroseismic reports.

All the more surprising was the occurrence of a sequence of four weak earthquakes in June 2014. Events originated near Hosteradice (SE margin of the 
Table 3 Changes of benchmark heights near Lanškroun town (+ up, - down), period 1948 -1993.

\begin{tabular}{lcccccccccccccc}
\hline Benchmark & 61 & 62 & 63 & 65 & 66 & 67 & 68 & 69 & 70 & 71 & 74 & 75 & 76 & 77 \\
Change (mm) & 0.0 & 0.0 & 0.0 & -1.1 & -8.7 & -14.1 & -13.7 & 7.0 & -9.3 & -7.3 & -9.5 & -38.5 & -6.8 & -4.9 \\
Benchmark & 79 & 80 & 81 & 82 & 83 & 85 & 86 & 88 & 0 & 0 & 0 & 0 & 0 & 0 \\
Change (mm) & -2.3 & -11.1 & -5.8 & -5.8 & 0.0 & -3.0 & 0.0 & 0.0 & 0.0 & 0.0 & 0.0 & 0.0 & 0.0 & 0.0 \\
\hline
\end{tabular}
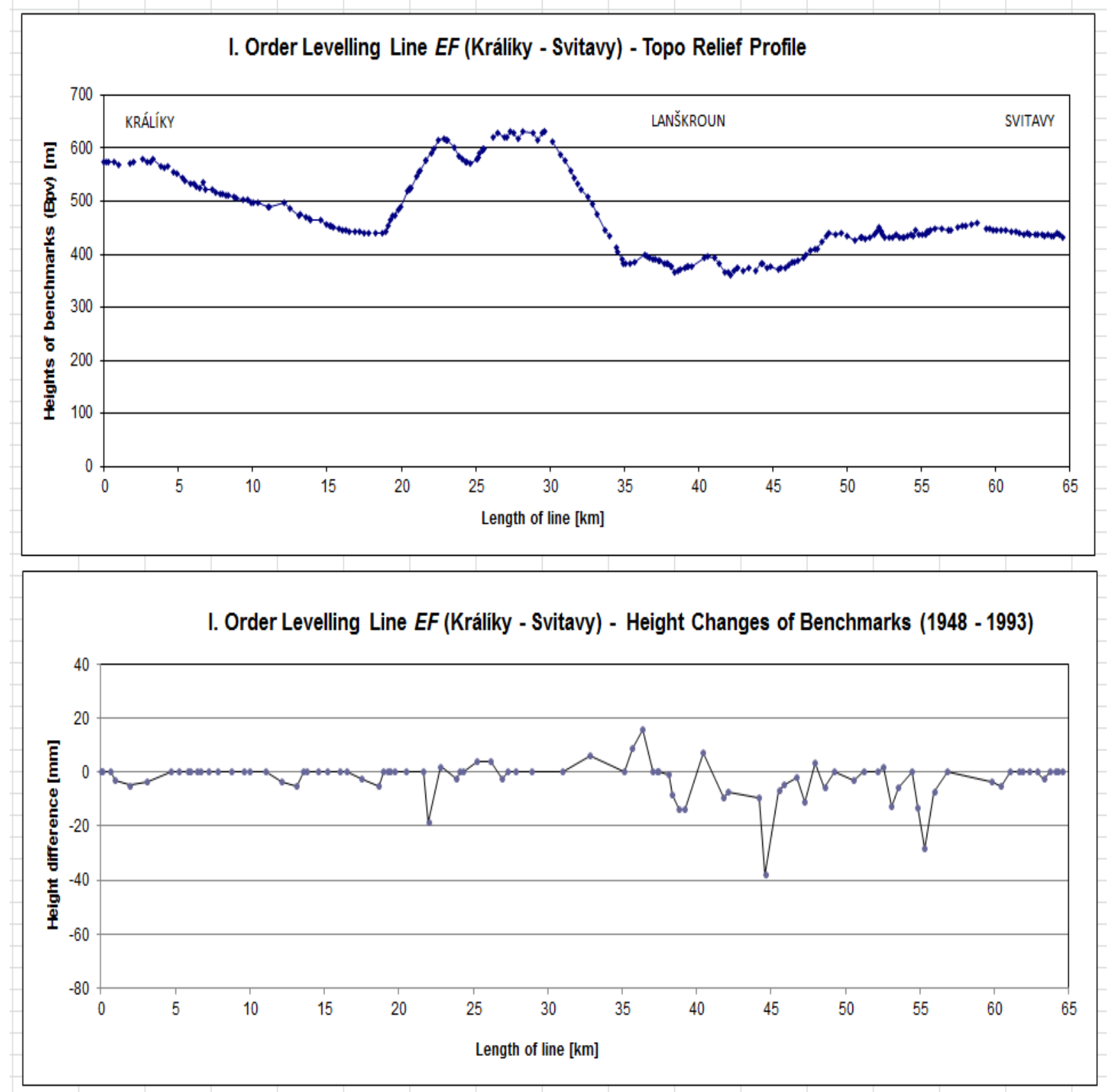

Fig. 12 Vertical changes of the benchmarks along the whole profile of the 1st order leveling line EF Králíky Svitavy.

Bohemian Massif), $40 \mathrm{~km}$ southwest of Brno. The strongest event reaching local magnitude of 2.0 occurred on June 1, 2014 at 00:43 UTC. It was felt by people close to the epicentre with the macroseismic intensity 4 EMS-98. A temporary seismic station was immediately installed in the epicentral area. The station recorded two of the four shocks and helped to confirm a focus position of the sequence: $48.95^{\circ} \mathrm{N}$, 16.24 E, depth 3 km (Pazdírková et al., 2015).

\section{CONCLUSIONS}

New GPS measurements realized in the MORAVA network in 2010-2014 period brought new results which were used for defining and proving the existence of kinematic active faults in eastern closing parts of the Bohemian Cretaceous Basin. Especially the faults crossing the northern part of the Boskovice Furrow - the ZHTTZ, Nectava-Konice and Králíky faults - represent intensive recently active features in this area. Its display can be followed in geodetic, geological, and geophysical data, and also in seismological data, which unambiguously prove recent activity. This recent activity ranks all these faults to the most critical areas in the Moravia territory. Intensive seismic activity surrounding the ZHTTZ, Boskovice Furrow and Nectava-Konice fault 
might from recent point of view (geodynamic and mainly seismotectonic) represent deep seated major kinematical boundary with reasonable impact on recent geodynamics of this region.

A few decades lasting intensive research offers new possibilities also for complex tectonic analyses of this contact area of the three basic units closing the Variscan orogeny - Saxothuringian, Bohemian and Moldanubian. To achieve better results for more comprehensive studies of the dynamics of the lithosphere of the Bohemian Massif they must be based on a combination of geodetic, geological and geophysical results that enable easier interpretation of recent geodynamic processes. For easier and faster updating of databases of observed phenomena it is necessary to realize direct GPS measurements at chosen places along mentioned faults at a network with higher density of points, which will be supplemented by geophysical profile measuring and the exogenous analyses on the base of aerial photos.

\section{ACKNOWLEDGEMENT}

The paper has been worked out under the project No. LO1408 "AdMaS UP - Advanced Materials, Structures and Technologies", supported by Ministry of Education, Youth and Sports under the „National Sustainability Programme I" and under the projects BD 12500028, BD 1240001012 and BD 12300008 supported by Brno University of Technology.

The morphological part of contribution was supported by long-term conceptual development subvention of research organizations RVO: 68145535 - Institute of Geonics of the CAS, v.v.i.

Especially we should like to thanks all students and $\mathrm{PhD}$ students of the Institute of Geodesy, Brno University of Technology, participating on the GNSS campaigns.

\section{REFERENCES}

Bábek, O., Tomek, Č., Melichar, R., Kalvoda, J. and Otava, J.: 2006, Structure on unmetamorphosed Variscan tectonic units of the southern Morava-Silesian zone, Bohemian Massif: a review. Neues Jahrbuch für Geologie und Paläontologie, Abhandlungen, 239, No. $1,37-75$.

Badura, J. and Rauch, M.: 2014, Tectonics of the Upper Nysa Kłodzka Graben, the Sudetes. Geologia Sudetica, 42, 137-148.

Čech, S., Klein, V., Kř́žž, J. and Valečka, J.: 1980, Revision of the Upper Cretaceous stratigraphy of the Bohemian Cretaceous Basin. Věstník ÚÚG, 55, 5, 277-296.

Cháb, J. et al.: 2007, Geological map of the Czech Republic 1: 500,000 - Czech Geological Survey, Prague.

Cícha, I. and Dornič, J.: 1959, Evolution of Boskovice Furrow Miocene between Tišnov and Ústí nad Orlicí. Sborník ÚÚG, geol., 26, 1, 393-434, (in Czech).

Dach, R., Hugentobler, U., Fridez, P. and Meindl, M.: 2007, Bernese GPS Software version 5.0. User manual. Astronomical Institute, University of Berne, Stampfli Publications AG, Bern.

Demek, J. and Kopecký, J.: 1998, Mt. Králický Sněžník (Czech Republic): Landforms and problem of
Pleistocene glaciation. Moravian Geographical Reports, 6, 2, 18-37.

Demek, J. and Mackovčin, P. (Eds.): 2006, Geographic lexicon of CR: Mountains and lowlands. Agentura ochrany př́rody a krajiny České republiky, Brno, 582 pp., (in Czech).

Demek, J., Kirchner, K., Mackovčin, P. and Slavík, P.: 2009, Morphostructures in the territory of the Czech Republic (Europe). Z. Geomorph., 53, Suppl. 2, 135144. DOI: $10.1127 / 0372-8854$

Digital elevation model of the $4^{\text {th }}$ generation: 2015 , Web of the Czech Office for Surveying, Mapping and Cadastre, Prague, (www.cuzk.cz - in Czech).

Dvořák, J., Friáková, O., Mitrenga, P. and Rejl, L.: 1984, Structural effect of the eastern Brno Massif segment on evolution of sedimentary cover formations. Věstník ÚÚG, 59, 1, 21-28, (in Czech).

Foldyna, J., Ratiborský, J., Kabeláč, J., Blažek, R., Grygar, R., Novák, J., Schenk, J., Gavlovský, E., Tyrner, M., Kubečka, E. and Mikulenka, V.: 1997, Final report of the grant project GA CR Nr. 105/94/1124 Monitoring the supracrustal blocks movements at the Bohemian Massif and Alpine-Carpathian Arc border by Global Positioning System (GPS) method. MS archive VŠB - Technical University Ostrava and CTU Prague, 51 pp., (in Czech).

Frejková, L.: 1960, Cretaceous formation between Svitavy and Letovice. Práce brněněnské základny ČSAV, Academia, Praha, 365-423, (in Czech).

Geographical database of CR: 2013, Web of the Czech Office for Surveying, Mapping and Cadastre, Prague, (www.cuzk.cz - in Czech).

Grygar, R. and Jelínek, J.: 2003, The Upper Morava and Nysa pull-apart grabens - the evidence of neotectonic dextral transtension on the Sudetic fault system. Acta Mont., Ser. A, 24, 51-59.

Hefty, J.: 2007, Geo-kinematics of Central and SouthEastern Europe resulting from combination of various regional GPS velocity fields. Acta Geodyn. Geomater., 4, No. 4 (148), 173-189.

Hefty, J., Hipmanová, L., Gerhátová, L., Igondová, M. and Drošćák, B.: 2010, Recent geo-kinematics of Slovakia based on homogenized solutions of permanent and epoch GPS network. Acta Geodyn. Geomater., 7, No. 3 (159), 303-315.

Hrádek, M.: 1982, Principles of structure-geomorphological classification and regionalization of the Bohemian Highlands. In: Geomorfological Conference, Charles University, Praha, 47-52, (in Czech).

Ivan, A.: 1991, Morphotectonics of the Křetínka river valley. In: Novák, V. (Ed.): Sborník referátů z geografického sympozia k 100. narození F. Vitáska, Institute of Geography of the CSAS, Brno, 105-117, (in Czech).

Ivan, A.: 1992, Morphotectonics on the contact of the Českomoravská vrchovina (Highland) and the Východočeská tabule (Tableland) in the surroundings of the town of Polička. In: Analysis of geographic systems. Institute of Geography of the CSAS, Brno, $157-168$.

Ivan, A.: 1996, Morphotectonics of SE margin of the Bohemian Cretaceous Basin, two half-grabens and their surroundings north of Brno (Moravia). Moravian Geographical Reports, 1, 4, 2-28.

Kachlík, V.: 2003, Geological development of the territory of the Czech Republic. SÚRAO, Praha, 64 pp., (in Czech). 
Kujal, R., Schenk, V. and Schenková, Z.: 2009, Gravity measurements in the region of the geodynamic network Highlands (the Bohemian Massif). Acta Geodyn. Geomater., 6, No. 2 (154), 155-161.

Lenhardt, W.A., Švancara, J., Melichar, P., Pazdírková, J., Havír, J. and Sýkorová, Z.: 2007, Seismic activity of the Alpine-Carpathian-Bohemian Massif region with regards to geological and potential field data. Geol. Carpathica, 58, 4, 397-412.

Malkovský, M.: 1977, Significant faults in the platform cover of the northern part of Bohemian Massif. Ústřední ústav geologický, Praha, 14, 30 pp., (in Czech).

Malkovský, M.: 1979, Tectonogeny of the platform cover of the Bohemian Massif. Ústřední ústav geologický, Praha, 53, 176 pp., (in Czech).

Malkovský, M., Benešová, Z., Čadek, J., Holub, V., Chaloupský, J., Jetel, J., Müller, V., Mašín, J. and Tásler, R.: 1974, Geology of the Bohemian Cretaceous Basin and its basement. Academia, Prague, 262 pp., (in Czech).

Pazdírková, J., Zedník, J., Prachař, I., Krumlová, H. and Zacherle, P.: 2015, The earthquake in Hostěradice in June 2014. Geologické výzkumy na Moravě a ve Slezsku, Brno, 22, 1-2, 61-64, (in Czech, English abstract). DOI: $10.5817 /$ GVMS2015-1-2-61

Pospíšil, L., Švábenský, O. and Weigel, J.: 2013, Movement tendencies in the Moravia region: Kinematical model. Acta Geodyn. Geomater., 10, 3(171), 307-321. DOI: $10.13168 /$ AGG.2013.0030

Pospíšil, L., Švábenský, O., Weigel, J. and Witiska, M.: 2009, Geodetic and geophysical analyses of DiendorfČebín tectonic zone. Acta Geodyn. Geomater., 6, No. 3 (155), 309-321.

Pospíšil, L., Švábenský, O., Weigel, J. and Witiska, M.: 2010, Geological constraints on the GPS and precise levelling measurements along the Diendorf-Čebín tectonic zone. Acta Geodyn. Geomater., 7, 3 (159), 317-333.

Roštínský, P., Pospíšil, L. and Švábenský, O.: 2013, Recent geodynamic and geomorphological analyses of the Diendorf-Čebín Tectonic Zone, Czech Republic. Tectonophysics, 599, 45-66. DOI:10.1016/j.tecto.2013.04.008

Schenk, V., Kottnauer, P., Schenková, Z., Rucký, A., Pšenička, J. anf Řehák J., jr.: 2002, Regional geodynamic network "WEST SUDETEN". A westward wide-ranging extension of present "EAST SUDETEN" network. Acta Montana, Ser. A, 20(124), 31-35.

Schenk, V., Schenková, Z., Cacoń, S., Kontny, B., Bosy, J. and Kottnauer, P.: 2003, To geodynamic interpretations of GPS data monitored on the EAST SUDETEN network. Acta Montana, Ser. A, 24(131), 87-97.

Schenk, V., Schenková, Z. Cajthamlová, M. and Fučík, Z.: 2010, GEONAS - geodynamic network of permanent GNSS stations within the Czech Republic. Acta Geodyn. Geomater., 7, 1 (157), 99-111.

Schenková, Z. and Kárník, V. (Eds.): 1985, Catalogue of earthquakes of Central and Eastern Europe. Manuscript, Geoph. Inst., CSAS, Praha, 67 pp.

Schenková, Z., Kottnauer, P., Schenk, V., CajthamlováGrácová, M., Mantlík, F. and Kujal, R.: 2009, Investigation of the recent crustal movements of the eastern part of the Bohemian Massif using GPS technology. Acta Research Reports, 18, 17-25.
Schenková, Z., Schenk, V., Mantlík, F. and Grácová, M.: 2007, Regional geodynamic network Highlands, the Bohemian Massif. Acta Geodyn. Geomater., 4, No. 4 (148), 207-215.

Skácelová, Z. and Havíř, J.: 1999, Earthquakes on the eastern margin of the Bohemian Massif recorded by the stations of the IPE Brno. Exploration Geophysics, Remote Sensing and Environment, 2(1998), 16-21.

Skácelová, Z., Rejchrt, M. and Mlčoch, B.: 2008, The 3D model of the crystalline basement of the Cretaceous sediments (Dlouhá mez region). Zprávy o geologických výzkumech v roce 2007, 49-53, (in Czech).

Svoboda, J. (Ed.): 1962, Explanation to the Geological map of Czechoslovakia, 1:200 000, Sheet M-33-XXIII.

Šalanský, K. and Gnojek, I.: 2002, Geomagnetic anomalies in the Czech Republic. Special Publication, Český geologický ústav, Praha, 134 pp., (in Czech).

Špaček, P., Bábek, O., Štěpančíková, P., Švancara, J., Pazdírková, J. and Sedláček, J.: 2015. The NysaMorava Zone: an active tectonic domain with Late Cenozoic sedimentary grabens in the Western Carpathians' foreland (NE Bohemian Massif). Int. J. Earth Sci., 104, 4, 963-990. DOI: $10.1007 / \mathrm{s} 00531-014-1121-7$

Špaček, P., Zacherle, P., Sýkorová, Z., Pazdírková, J. and Havír, J.: 2008, Microseismic activity of the Upper Morava Basin and surroundings. Sborník vědeckých prací VŠB-TU Ostrava, řada stavební, 8, 2, 287-295.

Švábenský, O., Pospíšil, L., Weigel, J., Roštínský P. and Witiska, M.: 2014, Results of repeated measurements at the Železné hory-Tišnov fault system and surroundings. Acta Geodyn. Geomater., 11, 3(175), 211-223. DOI: 10.13168/AGG.2014.009

Švábenský, O., Witiska, M., Ratiborský, J., Blažek, R. and Pospíšil, L., Weigel, J.: 2011, Preliminary results of repeated measurements in local geodynamic network Morava. Acta Geodyn. Geomater., 8, 3 (163), 291301.

Valečka, J.: 1988, Sedimentology of the Upper Cretaceous in the Králíky Graben (NE Bohemia). Sbor. geol. věd, geol., 43, 147-191, (in Czech).

Valečka, J. and Skoček, V.: 1990, Lithoevents in the Czech Cretaceous Basin. Věstník ÚÚG, Prague, 65, 1, 1328, (in Czech).

Valigurský, L. and Čech, S.: 2003, Ideological morphotectonic evolutionary model of the Ústí nad Orlicí Furrow. In: Mentlík, P. (Ed.), Geomorfologický sborník, Západočeská univerzita, Plzeň, 2, 259-263, (in Czech).

Vavř́nová, M.: 1946, Geology of the south-western piedmont of the Orlické hory Mts. and the surroundings of Kyšperk and its Saxon tectonics. Sborník SGÚ, Praha, 13, 342-376, (in Czech).

Vyskočil, P.: 1996, Recent crustal movements, their properties and results of studies in the territory of Czech Republic. In: Seismicity, neotectonics, and recent dynamics with special regard to the territory of the Czech Republic, VUGTK Zdiby, 42, 15, 77-120.

Vyskočil, P. and Zeman, A.: 1980, Problems and existing results of the recent Earth surface movement studies on the Bohemian Massif and the Western Carpathian contact. Čas. Mineral. Geol., Praha, 25, 4, 389-406, (in Czech). 


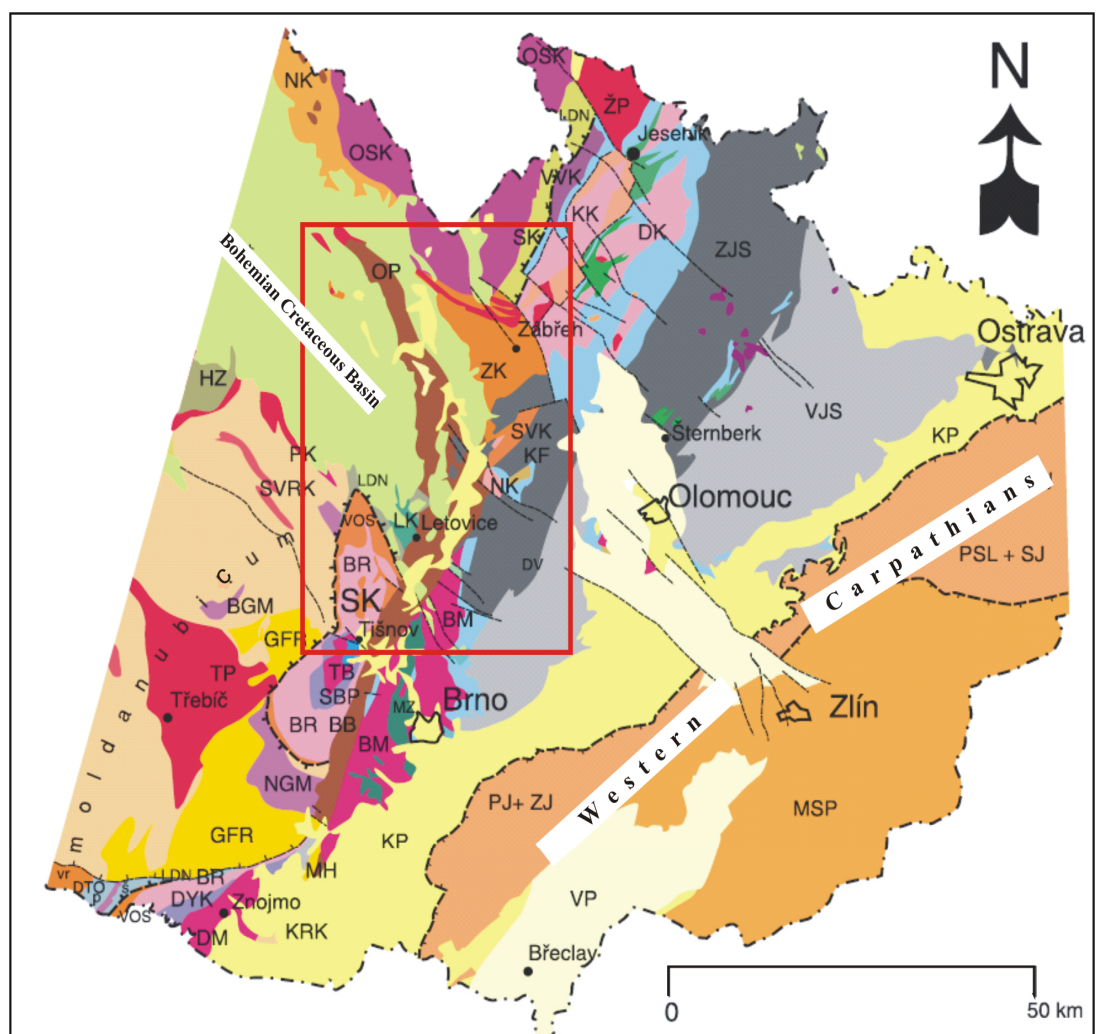

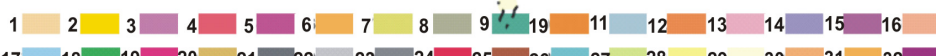
$\begin{array}{lllllllllllllllll}17 & 18 & 19 & 20 & 21 & 22 & 23 & 24 & 25 & 26 & 27 & 28 & 29 & 30 & 31 & 32\end{array}$ Kachlík, 2003). Explanations: Moldanubian area s. I. (i.e. including the Svratka Crystalline (SVRK) and Polička Crystalline (PK):

1 mainly gneisses and migmatites with bright inserts, undifferentiated (including the Krhovice Crystalline - KRK); 2 Gföhl gneisses (GFR), migmatites (including southern part of the Miroslav Horst Crystalline - MH); $\mathbf{3}$ Granulite massifs with bodies of basic and ultrabasic

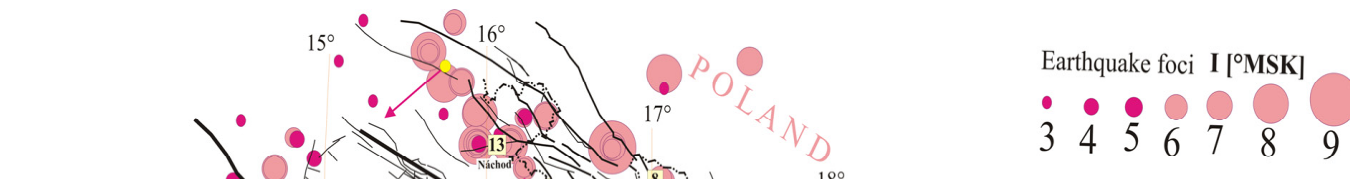

rocks - Náměšt' Granulite Massif, Bory Granulite Massif (NGM); 4 apparently Cambrian-Ordovician gneisses. Lugicum area:

5 gneisses and migmatites of the Orlice-Sněžník Vault core (OSK), including the lower metamorphic metasediments of the Stroński group; 6 Nové Město Crystalline - NmK (undifferentiated); 7 Staré Město Crystalline SK (undifferentiated); Letovice Crystalline (LK): 8 schists and gneisses with metabasite insertions; 9 Letovice Meta-Ophiolite Complex; 10 Zábřeh Crystalline (ZK) undifferentiated. Moravian-Silesicum: Moravicum of the

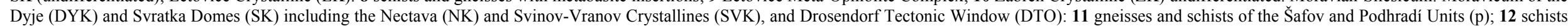

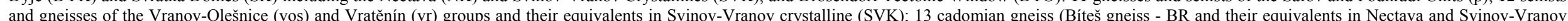

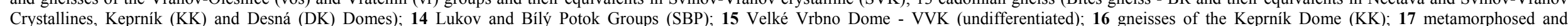

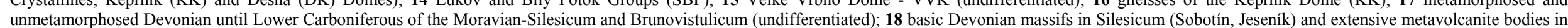
the Jeseník Culm basement. Brunovistulian: 19 Cadomian plutonics ( Brno Massif - BM), including the metabasite zone - (MZ), Dyje Massif (DM) and occurrences in the Upper Morava Valley; 20 Kladky phyllites (KF); 21 Lower Carboniferous mainly in flysch development (undifferentiated) of the Západni Jeseníky Synclinorium (ZJS) and the western part of Drahany Highlands; 22 Vises flysch of the Drahany Highlands (DV) and the Eastern Jeseníky Mts. synclinorium (VJS); 23 Namurian of the Upper Silesian Basin; 24 Variscan plutonites - Třebič Pluton (TP), Žulová Pluton (ŽP), smaller bodies without marking. Platform units: 25 PermianCarboniferous of the Boskovice Furrow (BB), the Orlice basin (OP) and relicts in the Orlické Hory Mts.; 26 Jurassic (limestones, sandstones); 27 Cretaceous of the Bohemian Cretaceous Basin, the Králíky Graben, relics in the Blansko Rift, relics of the Osoblaha Basin projections. Carpathian System: 28 Tertiary of the Carpathian Foredeep including relics in the eastern part of BM; 29 Pliocene of the Vienna Basin (VP) and Upper Morava Valley; 30 complexes of Pouzdřany (PJ), Ždánice (Rev.) Lower Silesia (PSJ) and Silesia (SJ) Units - (Jurassic till Tertiary); 31 mostly Paleogene flysch complexes of Magura nappe group (MSP); 32 Neovolcanites of BM, 


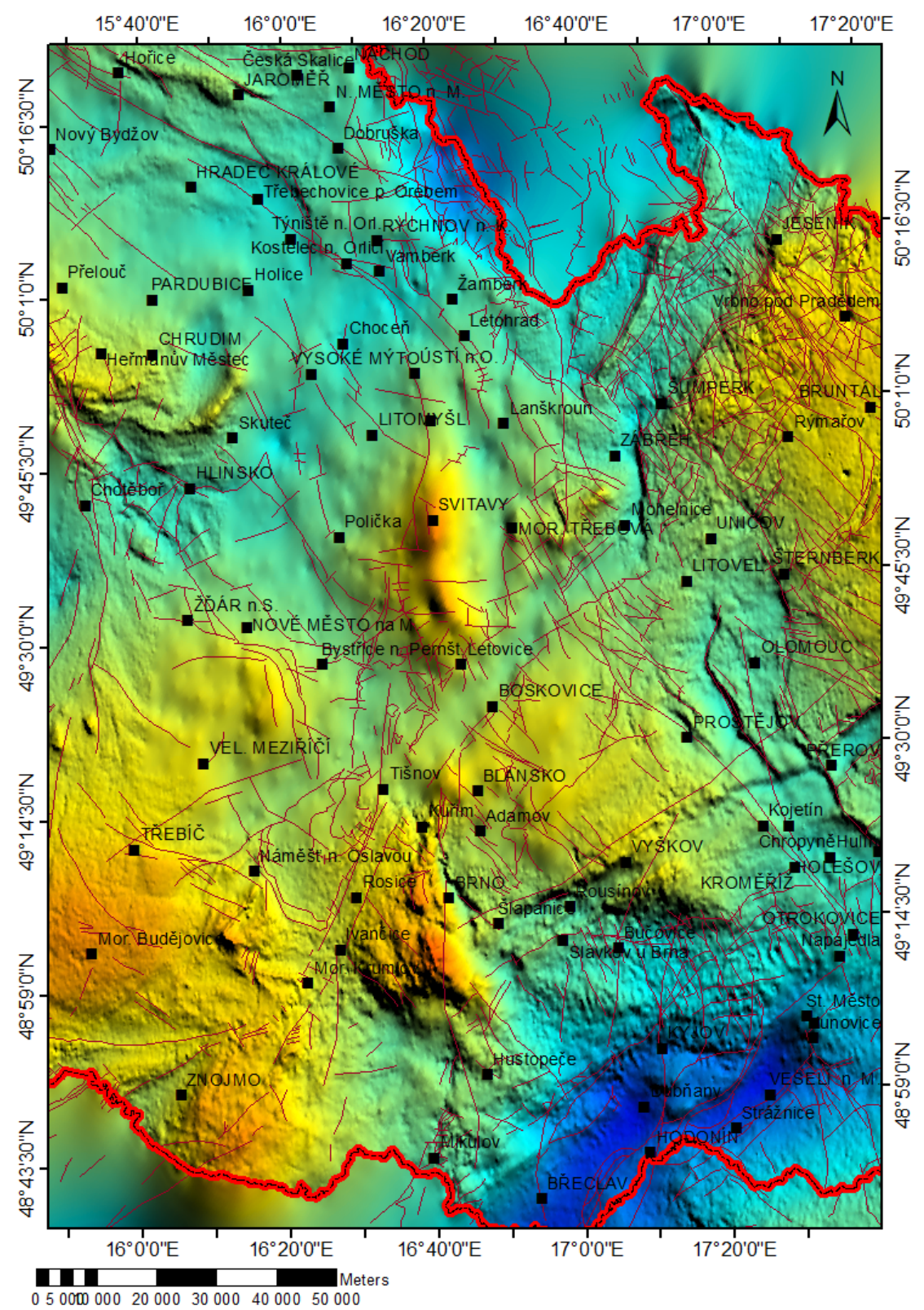

Fig. 3 Gravity and magnetic maps of area of interest and its surroundings.

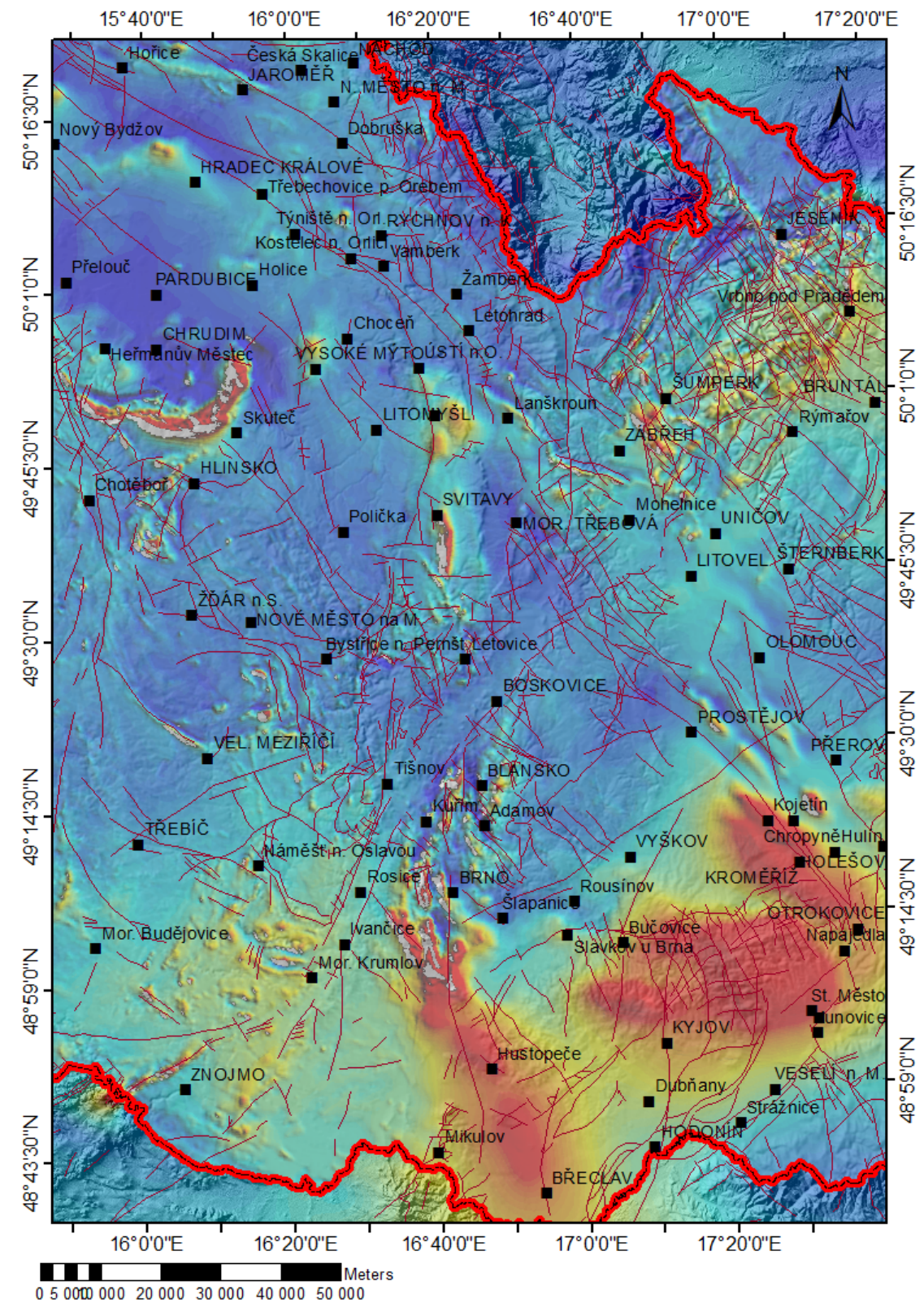




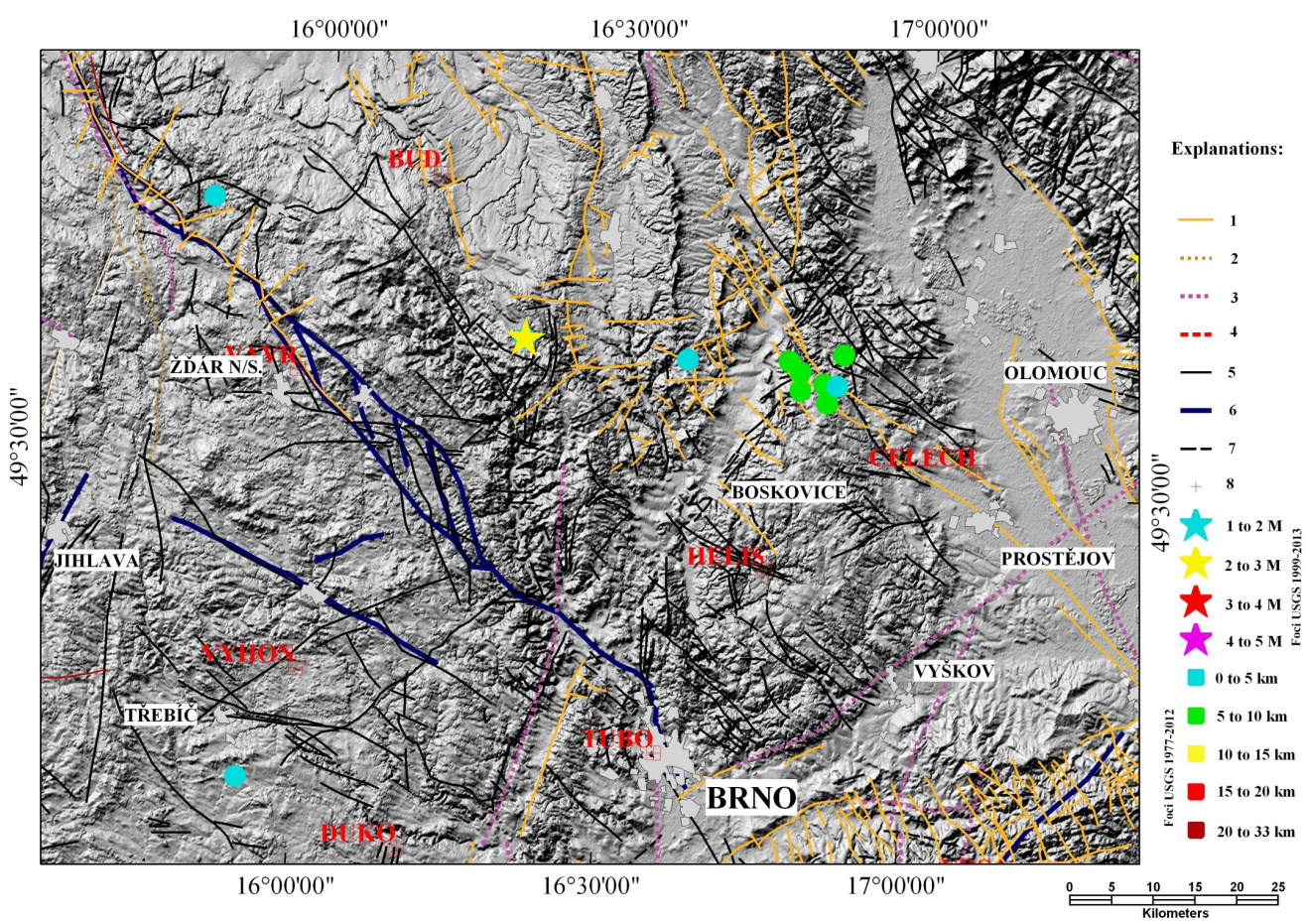

Fig. 4 Detail view on the distribution of the earthquake foci with higher magnitude north of the Boskovice town and their relationship to known tectonics. Southern part is influenced by the Železné Hory - Tišnov Tectonic Zone which creates a very important morphological feature (Švábenský et al., 2014). Explanation: 1- geological fault, 2 mylonitized zone, 3 - boundary active in RVM map, 4 - boundary after Remote Sensing Data, 5 - boundary after geophysics, 6 - recently active fault, 7 - supposed fault, 8 - GPS station, bellow the foci after USGS database for the period 1977 to 2013.

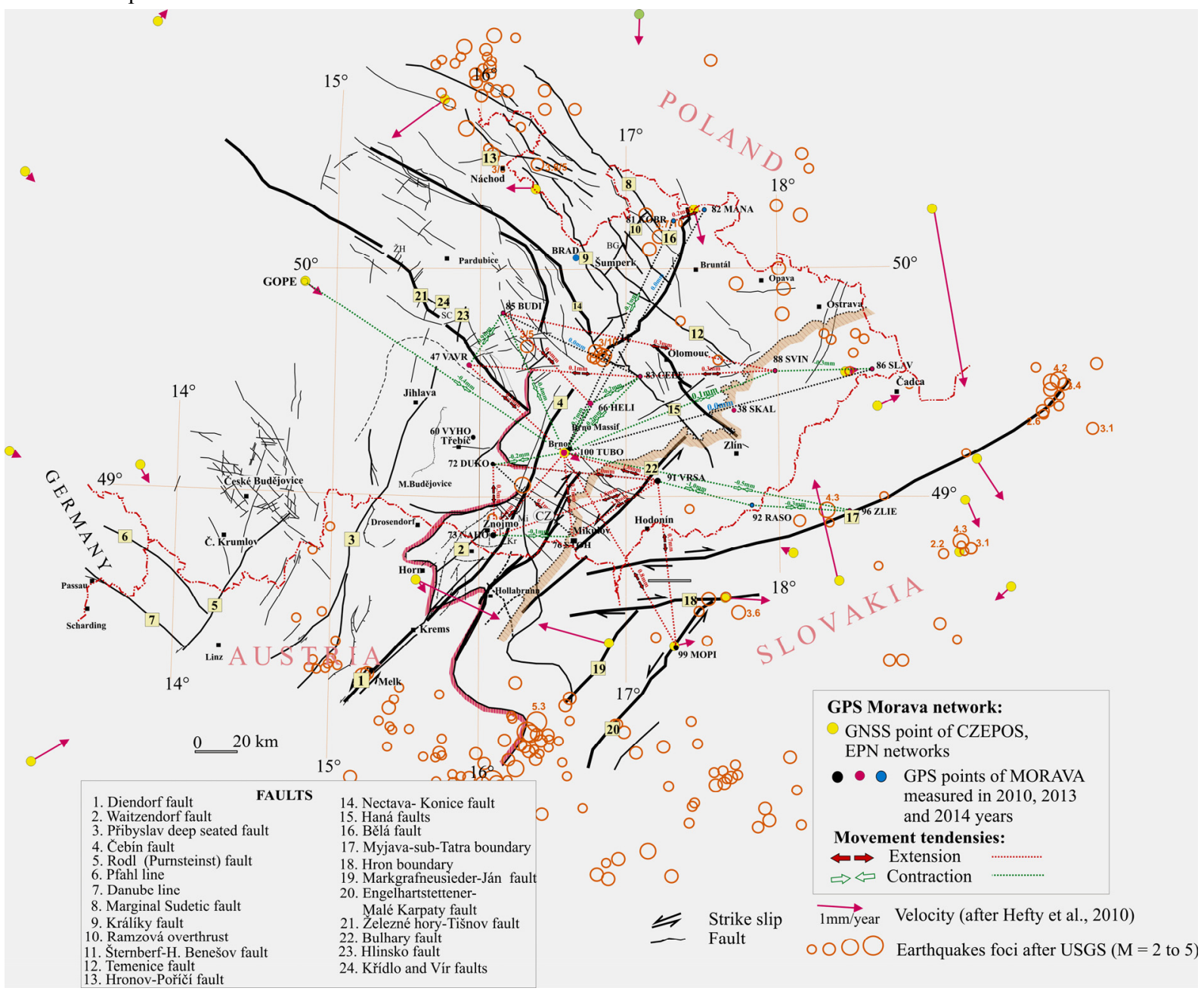

Fig. 5 Tectonic scheme and its correlation with movement tendencies determined on the bases of monitoring at the GNSS MORAVA network. 
L. Pospišil et al.

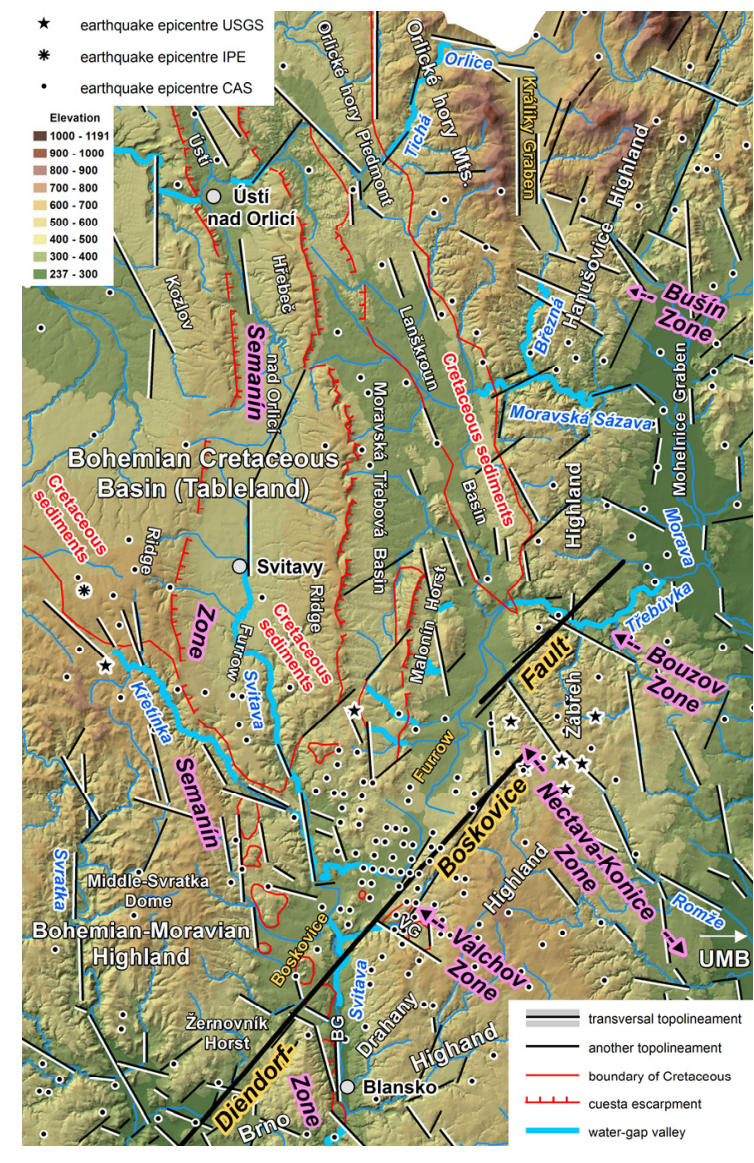

Fig. 6 Digital elevation model of the NE Boskovice Furrow and Králíky Graben area with an indication of main landforms, completed with derived topolineaments and their basic interpretation. UMB - Upper Morava Basin; BG Blansko Graben; VG - Vachov Graben.

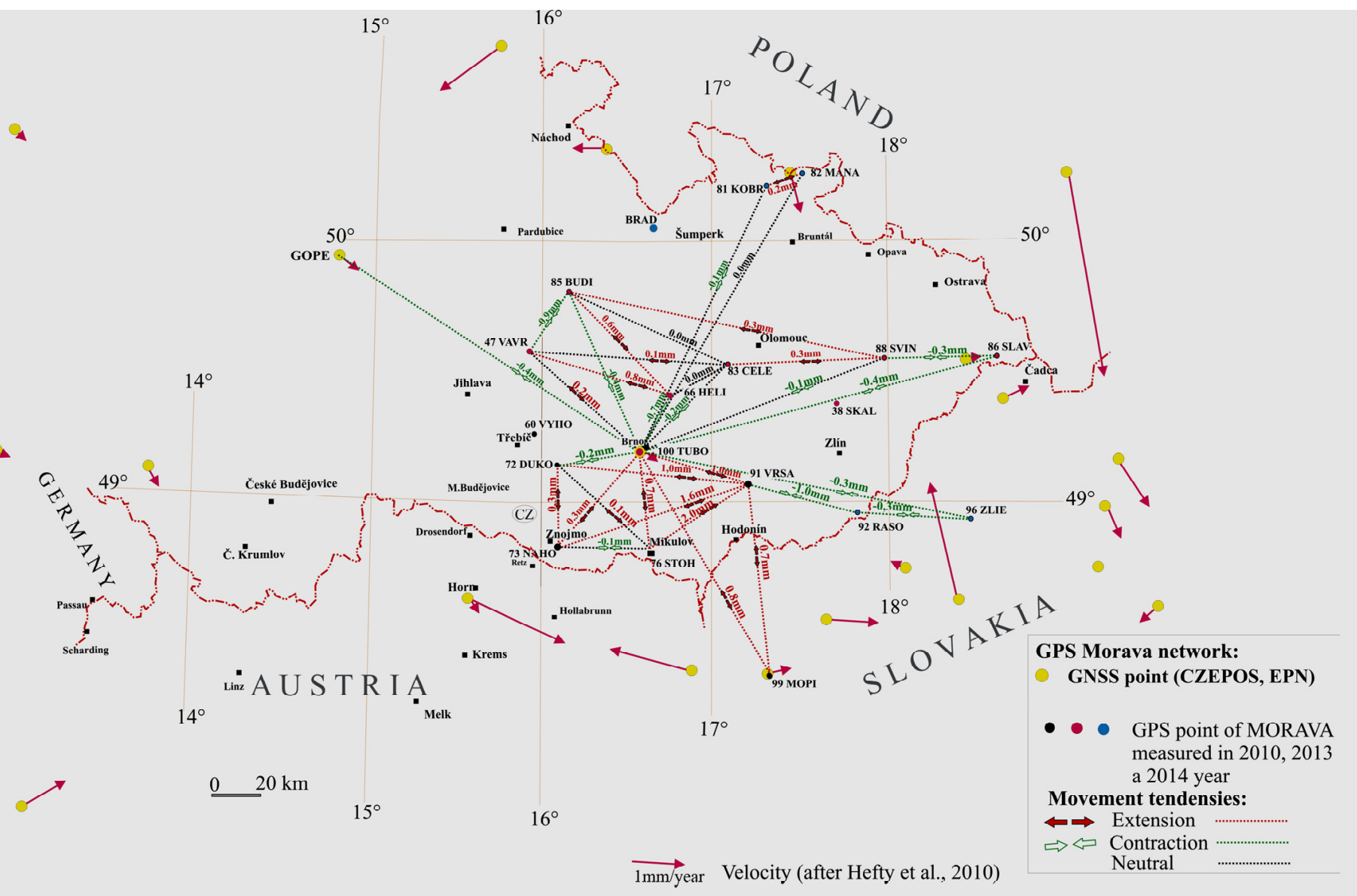

Fig. 8 Complete annual velocities in MORAVA network. 


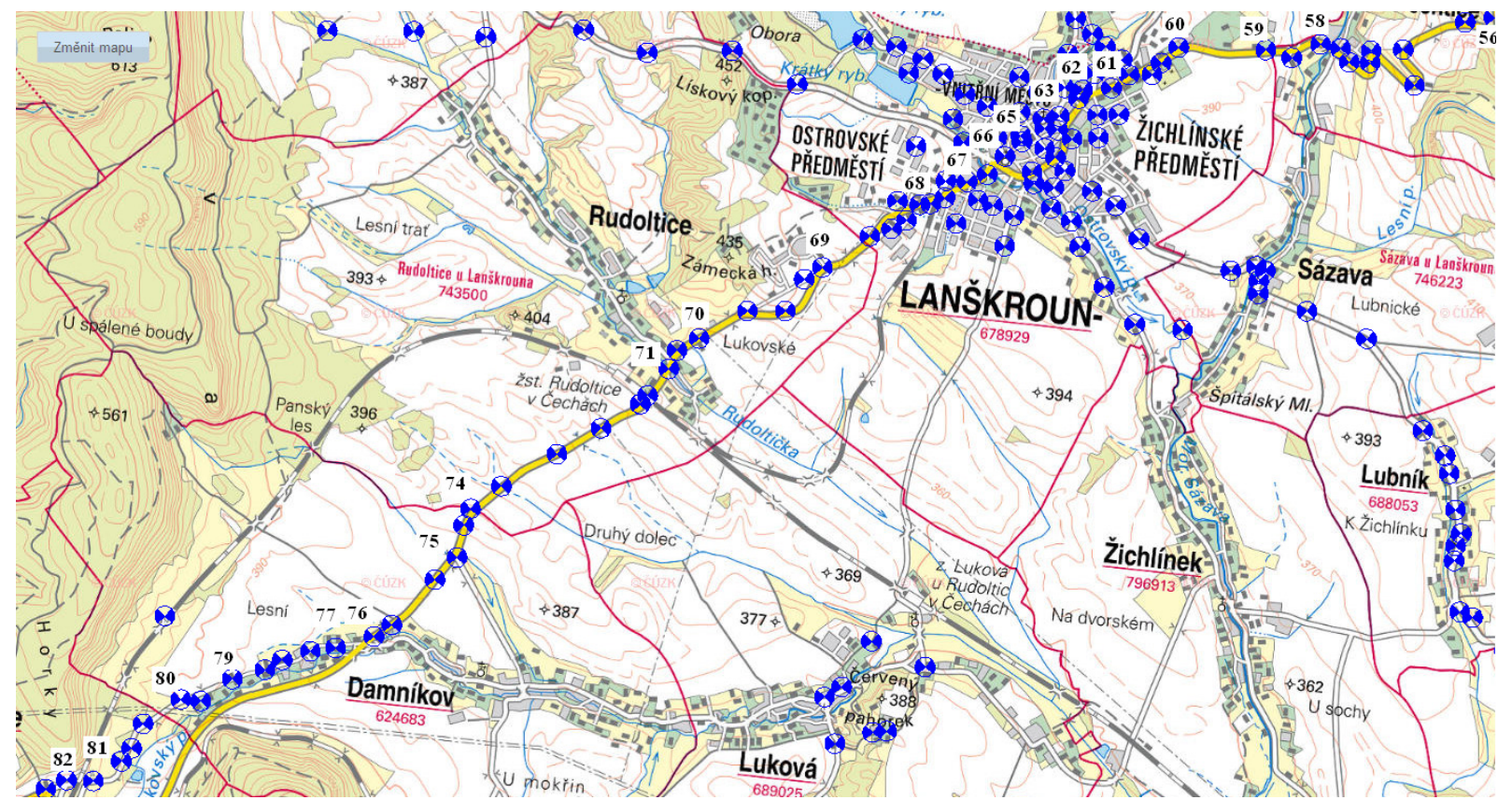

Fig. 10 Order leveling line $E F$ (Králiky - Svitavy) - part between points $E F-56$ and $E F-82$. The map is supplemented by part of geological profile crossing the study area (thin red dotted line - Fig.11). Arrow indicates the change of movement trend. Brown dotted line is position of the Nectava - Konice Tectonic Zone.

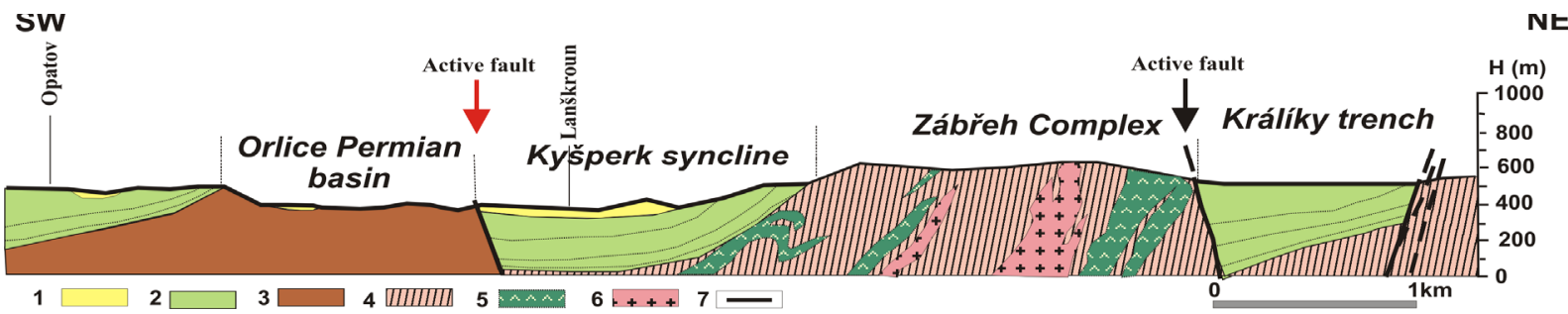

Fig. 11 Position of the active Nectava - Konice Tectonic Zone is detected by Repeated Leveling Profile (RLP) near the Lanškroun town. On the geological section (modified after Geological map ČSSR, Sheet Moravská Třebová-ÚÚG Praha) is identified by red arrow. Most fall down is registered closer to central zone of Kyšperk syncline, near to Lanškroun. Explanations: 1- Neogene (Lower Badenian), 2- Cretaceous (Cenomanian to Coniacian), 3- Paleozoic (Permian), 4- Proterozoic (biotitic gneisses, phyllites, shists, paragneisses), 5- Amphibolites and eclogites, 6-Diorites and granitodiorites (tonalities), 7-faults.

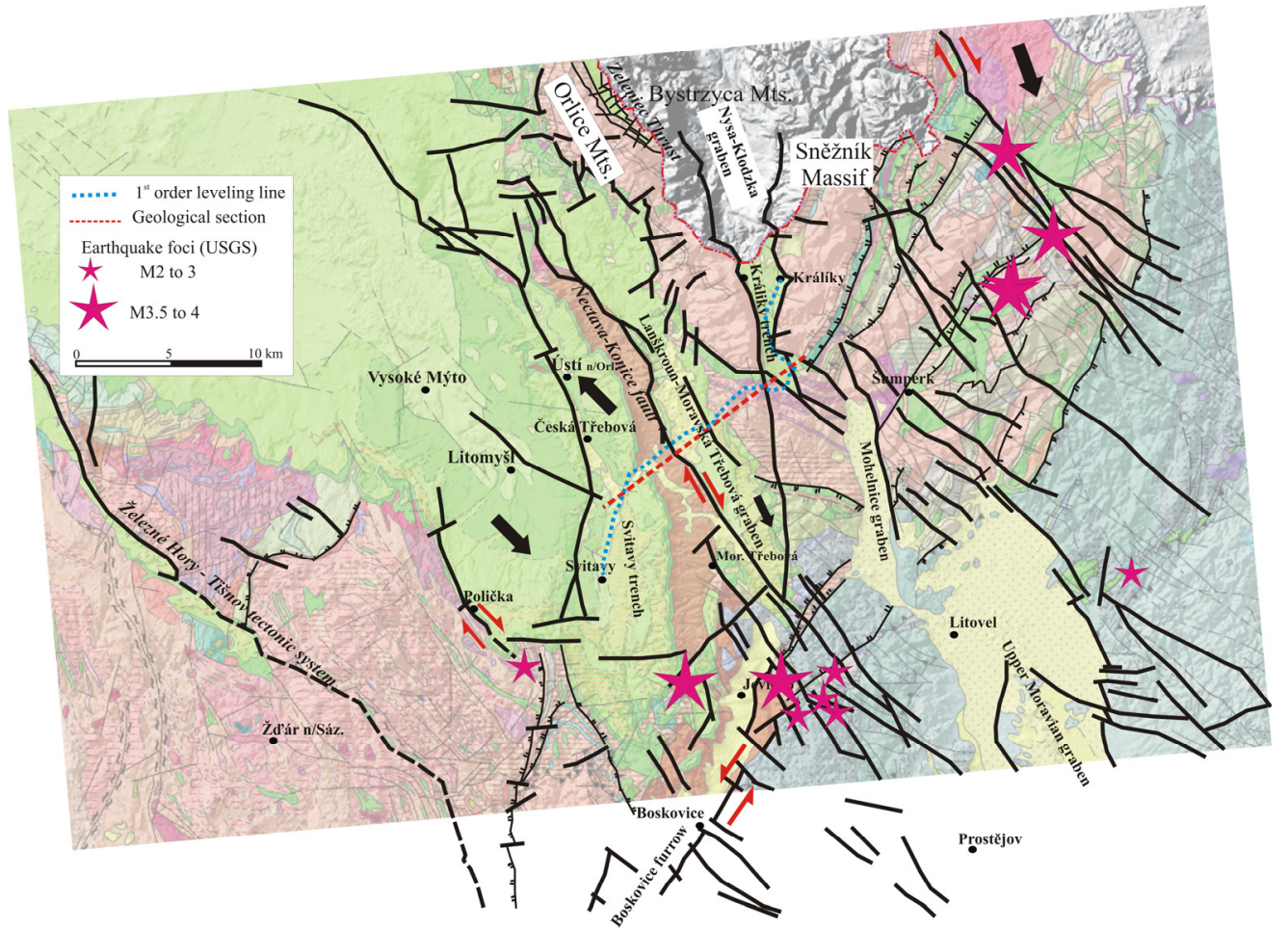

Fig. 13 Geodynamic model of the northern part of Boskovice Furrow. Red arrows indicate the sense of movement along the faults interpreted on base of the GNSS measurements 